\title{
Financial connectivity and excessive liquidity: Benefit or risk? ${ }^{\text {th }}$
}

\author{
Müge Demir*, Zeynep Önder \\ Faculty of Business Administration, Bilkent University, Ankara, Turkey
}

\section{A R T I C L E I N F O}

\section{Article history:}

Received 24 March 2019

Accepted 15 July 2019

Available online 16 July 2019

\section{JEL Classification:}

F21

F34

F65

G01

G19

\section{Keywords:}

Cross-border banking

Network analysis

Financial connectivity

Systemic crises

\begin{abstract}
A B S T R A C T
This paper explores the structure of cross-border lending market by using network analysis and examines the relationship between financial connectivity and probability of systemic crises during normal, credit boom and capital inflow upsurge periods, controlling for macroeconomic variables. A country-level panel data set for bank-to-bank and bank-tonon-bank cross-border lending markets of 13 advanced economies is used in the analysis for the 1978-2016 period. We find that a rise in financial connectivity reduces the probability of systemic crises. However, this effect is found to be mitigated or completely eliminated in credit boom and capital inflow upsurge periods in both markets. The findings suggest that bank-to-non-bank lending market is more stable in terms of both the number and the amount of lending relationships and recovered faster than bank-to-bank lending market following the recent global financial crisis.
\end{abstract}

(c) 2019 Elsevier B.V. All rights reserved.

\section{Introduction}

The global financial crisis (GFC) has increased the interest in understanding the relationship between financial connectivity and financial stability. In the literature, there are two conflicting arguments on this relationship. On the one hand, it is argued that an increase in the level of financial connectivity enhances financial stability by allowing financial institutions to absorb the negative impacts of a shock among many counterparties through risk sharing (Allen and Gale, 2000). On the other hand, depending on the structure of the financial system, it can also deteriorate financial stability by facilitating the spread of a shock from one institution to another, leading to an increase in systemic risk (Gai and Kapadia, 2010; Nier et al., 2007 and many others). In this study, we analyze the relationship between financial stability and financial connectivity in bank-to-bank (BB) and bank-to-non-bank (BNB) cross-border lending market of 13 advanced countries ${ }^{1}$ during the 1978-2016 period. We employ network analysis which is a useful tool for modelling linkages across countries to understand the structure of the cross-border lending market and to measure its connectivity. ${ }^{2}$

\footnotetext{
This paper is a part of Müge Demir's Ph.D. study in the Faculty of Business Administration in I.D. Bilkent University.

* Corresponding author.

E-mail address: muged@bilkent.edu.tr (M. Demir).

${ }^{1}$ We examine only advanced countries because any crisis initiated in the developed countries is likely to have more detrimental effects on the rest of the world, as observed in the recent GFC. Cross-border flows among these countries represent more than $85 \%$ of global cross-border flows.

${ }^{2}$ For examples of the use of network analysis to examine financial crisis, see Allen et al. (2009). For a review of different applications of network analysis in finance, see Allen and Babus (2009).
} 
We try to answer the following questions: (i) is there a relationship between financial connectivity and financial stability measured by the probability of systemic crisis? (ii) does the observed relationship between financial stability and financial connectivity among advanced economies change in credit boom and capital inflow periods? Excessive liquidity periods have a potential to cause systemic crisis by facilitating negative spillover effects across countries through cross-border holdings, as observed in the recent GFC. Empirical literature show that credit boom and capital inflow periods at which system is exposed to excessive liquidity, are associated with higher probability of crisis and instabilities in developed countries (e.g., Schularick and Taylor, 2012; Jord et al., 2011; Caballero, 2014).

We analyze cross border flows going to banking and non-banking sector, separately, because differences in characteristics of the borrowing sector may affect the relationship between financial connectivity and the probability of crisis. For example, cross-border lenders incur higher monitoring efforts with respect to the non-bank borrowers (e.g. Martinez, 2015; Avdjiev et al., 2018). The shorter maturity of BB loans compared to BNB loans makes it easier to cut back lending and may cause instabilities (Aiyar et al., 2014). The relation between the borrowing sector and the phase of the credit cycle that the economy underwent are likely to affect the relationship between the probability of crisis and the level of connectivity in each lending market. In Avdjiev et al. (2018) study, while BB cross-border lending is found to be associated with credit booms, BNB lending is found to be associated with credit busts. One may expect this result as BB lending has a potential to accelerate the money creation process, leading to a credit boom whereas BNB lending has a potential to be channeled to real economy through investments.

Our paper contributes to the literature in three ways. First, we show that the observed relationship between financial connectivity and the probability of crisis changes during excessive liquidity periods, represented by credit boom and capital inflow periods in both networks. Second, we show that this relationship also depends on the type of the borrowing sector: banking versus non-banking. Third, the time coverage of the data allows us to analyze all systemic crises within the period of 1978-2016, including the recent GFC as well as the 2014 European debt crisis.

We find that an increase in the level of financial connectivity among advanced economies reduces the probability of systemic crises controlling for macroeconomic and other country characteristics. However, this effect is found to be mitigated or completely eliminated in credit boom and capital inflow periods. In particular, we find that an increase in the level of connectivity has a substantial destabilizing effect during credit boom periods in BB lending market, but we do not observe this effect in BNB lending market. On the other hand, an increase in the level of connectivity during capital inflow periods is found to have destabilizing effects in both markets, but the effect is found to be limited to short-term in the BNB lending market. The results of network analysis indicate that cross-border flows and connectivity decrease considerably in the year when the GFC hit a country; a funding shift may have occurred from bank towards non-bank sector lending during crisis periods; and BNB lending market is more stable both in terms of the number and the amount of lending relationships and recovered faster than the BB lending market following the GFC.

The paper is organized as follows. Section 2 discusses the related literature. Section 3 explains the hypotheses, empirical model and data used in the analysis. Section 4 presents the network characteristics of both BB and BNB cross-border lending markets. The results of the analysis of the relationship between financial connectivity and the probability of crisis are reported in Section 5. The final section concludes the paper.

\section{Literature review}

Theoretical literature argues that the financial stability of the system depends crucially on the level of connectivity among financial institutions. In their pioneering work, Allen and Gale (2000) show that complete networks, in which all possible symmetric bilateral relationships exist among banks, are much more resilient to liquidity shocks than incomplete networks, in which banks are only linked to one bank. The literature developed in the aftermath of the GFC has challenged the view and argued that the effect of financial connectivity on financial stability depends on several factors such as the characteristics of the market and the shock (e.g., Gai and Kapadia, 2010; Nier et al., 2007; Battiston et al., 2012a; Brusco and Castiglionesi, 2007; Battiston et al., 2012b; Elliott et al., 2014; Allen et al., 2012; Caccioli et al., 2014; Acemoglu et al., 2015).

Although several theoretical studies show that network structure is important in understanding the systems resilience to systemic crisis, the empirical evidence is relatively scarce. For example, in an effort to relate network characteristics to changes in the global banking system, by using the BIS cross-country data set similar to ours, Minoiu and Reyes (2013) show that the level of connectivity of the global banking network rises before banking and debt crises and diminishes in the aftermath, for 184 countries during 1978-2010 period. Similarly, by using BIS consolidated cross-border exposure data, Hattori and Suda (2007) construct a network of cross-country exposures during the 1985-2006 period for 215 countries and find that an increase in connectivity level of the global banking network improves efficiency of international financial markets, but it is also likely to increase the systemic risk in the market. Using a more granular bank-level dataset on the syndicated loan market for the period 1980-2009, Hale (2012) shows that following the GFC, banks experience larger declines in their cross-border lending and in the formation of new lending relationships. Our work improves upon this line of literature because it relates network characteristics with the probability of crisis and differentiates normal versus excessive liquidity periods as well as the type of the borrowing sector; bank and non-banking sector.

Some empirical studies examine whether financial connectivity measured by network analysis could be used as an early warning indicator in predicting the incidence and the severity of crisis. For example, by using several network statistics and 
bank-level detailed data on global syndicated loan market for the period 1980-2007, Caballero (2015) calculates a financial integration measure for the global banking network and finds that it is an important determinant of banking crisis. Chinazzi et al. (2013) identify a relationship between the 2008-2009 crisis and global banking network constructed with bilateral cross-country debt flow and equity investments data. Similarly, based on the network built with BIS bilateral locational statistics, Minoiu et al. (2015) show that financial connectivity measures estimated by using network analysis have early warning potential in predicting systemic banking crisis. Although our aim is not to study the early warning power of financial connectivity as derived from network statistics, we use the outcomes of these papers as a rationale for examining the relationship between financial connectivity and the probability of crisis. In our analysis, we aim to contribute to the literature by demonstrating the relationship between financial connectivity and the probability of systemic crisis in BB and BNB lending networks and how this relationship changes with the type of the borrower (bank and non-bank) and during the periods with excessive liquidity, as excess liquidity could facilitate the unintended consequences of a crisis across countries.

\section{Methodology}

\subsection{Hypotheses and empirical model}

Based on the existing literature, first we test whether there is a negative relationship between financial connectivity and the probability of systemic crisis, controlling for macroeconomic and country characteristics. Second, we test whether the observed relationship changes in credit boom and capital inflow periods at which there is excess liquidity in the market. Hypotheses are tested separately for BB and BNB lending networks.

The following probit models are estimated to test the hypotheses by using the annual bilateral cross-border exposures of 13 advanced economies ${ }^{3}$ during the 1978-2016 period:

$$
\begin{aligned}
& P\left(\text { crisis }_{i t}=1 \mid C_{i t}, D_{i t}, X_{i t}\right)=\Phi\left(\alpha_{i}+\beta_{1} \cdot C_{i t}+\beta_{2} \cdot D_{i t}+\Gamma \cdot X_{i t}\right) \\
& P\left(\text { crisis }_{i t}=1 \mid C_{i t}, D_{i t}, X_{i t}\right)=\Phi\left(\alpha_{i}+\beta_{1} \cdot C_{i t}+\beta_{2} \cdot D_{i t}+\beta_{3} \cdot C_{i t} \cdot D_{i t}+\Gamma \cdot X_{i t}\right)
\end{aligned}
$$

where $i$ and $t$ stand for country and time, respectively. The dependent variable is a financial stability indicator that takes a value of 1 if there is a systemic crisis in country $i$ in year $t$, and 0 otherwise. $C_{i t}$ represents financial connectivity measure. It is measured for the overall network (globally) and for individual countries (locally). $D_{i t}$ corresponds to a dummy variable taking a value of 1 in credit boom or capital inflow periods, and 0 otherwise. $X_{i t}$ represents a vector of macroeconomic control variables and $\alpha_{i}$ represents the country fixed effects. The models are estimated with the lagged values of connectivity measures and dummy variables, as well to analyze whether the impact of financial connectivity and excessive liquidity on the probability of crisis changes with lag.

Financial connectivity is calculated by using three connectivity measures of network analysis. The first one measures connectivity of the overall network. The other two measure the unweighted and weighted connectivity of a country where weights are determined by the normalized cross-border flows between any two countries. These measures are estimated for BB and BNB lending networks, separately. We also investigate whether the results are sensitive to the connectivity measure used in the analysis.

Based on the results of Allen and Gale (2000), the coefficient of $\beta_{1}$ is expected to be negative; that's an increase in financial connectivity would reduce the probability of crisis through risk-sharing and liquidity allocation. In credit boom and/or capital inflow periods, we expect this effect to deteriorate because increased liquidity could facilitate the distribution of negative spillovers among countries, as documented in the theoretical and empirical literature. Hence, the coefficient of the interaction variable between financial connectivity and the dummy variable indicating credit boom or capital inflow periods, namely $\beta_{3}$, is expected to be positive. The significance of this coefficient will be more pronounced in the BB lending network than the BNB lending network because banking sector lending may enhance credit boom through money creation process whereas BNB lending does not enhance booms as loans are channeled into real economy. Finally, both theoretical and the empirical literature predict a positive coefficient for dummy variables indicating capital inflows and credit boom periods, as booms and inflows are found to be associated with financial crisis in developed countries.

\subsection{Definition of variables}

Crisis variable: We use the systemic crisis definition of the European Systemic Risk Board (Lo Duca et al., 2017). They determine the start and the end dates of crises in European countries by using a quantitative approach based on a financial stress index and an expert judgment from national and European authorities. They assume that a crisis starts if at least one of the following occurs in that year: "(i) the emergence of systemic financial stress in asset markets, (ii) the first policy response in relation to the crisis, or (iii) the first failure of a major market player, depending on which date is earlier and/or considered appropriate by national authorities (Lo Duca et al., 2017)." The end date of a crisis is defined as a date when the post-crisis

\footnotetext{
${ }^{3}$ These countries are Belgium, Denmark, France, Finland, Germany, Ireland, Japan, Luxembourg, Netherlands, Sweden, Switzerland, UK and US.
} 
adjustment period is completed, and fiscal and monetary policies become broadly neutral. ${ }^{4}$ The systemic crisis dates for $11 \mathrm{EU}$ countries are taken from Lo Duca et al. (2017). The crisis dates for Japan and US are retrieved from Laeven and Valencia (2013). ${ }^{5}$

Financial connectivity measures ${ }^{6}$ : Financial connectivity measures are estimated by using network analysis. In the network analysis, each country represents a node, and cross-border lending relationships across countries represent links. The links are weighted by normalized cross-border flows across countries. The network is assumed to be directed as there are crossborder flows from a lender to a borrower country, but not necessarily vice versa. Each year is modelled as a separate, weighted and directed network. Three measures are used in estimating financial connectivity. They are network density (also known as global financial connectivity, FC), binary clustering coefficient (BCC), and weighted clustering coefficient (WCC).

FC measures the global connectivity level of a network in the year $t$. It is defined as the number of links observed in the network divided by the total possible number of links. It represents the probability of a connection between two countries in the network. This statistic is widely used in the literature to define the topology of the overall network (see Minoiu and Reyes, 2013; Minoiu et al., 2015; Chinazzi et al. 2013; Hale, 2012; Hattori and Suda, 2007; Caballero, 2015).

The second connectivity variable, BCC measures a country's own level of (i.e., local) connectivity within the network. It expresses the likelihood that any two counterparties of a country are also counterparties of themselves. In other words, it is the probability that two counterparties of a country are connected to each other so that all three form a closed triangle pattern relationship. In estimating financial connectivity, BCC assumes an unweighted and directed network. Similar to FC, BCC ignores the amount of cross-border flows between countries and considers only the number of lending relationships across countries. Its value ranges between 0 and 1 ; such that the higher the value of the BCC, the higher the probability of the country to form tightly connected neighborhoods. ${ }^{7}$

The third measure of financial connectivity, WCC also measures a country's local connectivity level. Unlike BCC, it estimates the weighted probability that two counterparties of a country are also counterparties among themselves by putting more weight on stronger interactions with higher amount of cross-border flows. The weighted network analysis is particularly essential because it might provide different insights regarding the network characteristics, as there has been significant increase in size of the cross-border flows during recent years. By definition, the higher the BCC and cross-border flows, the higher the value of WCC; the higher the number of countries that country of interest borrows or lends (i.e. counterparties of a country), the lower the WCC, due to the denominator effect. Any increase in WCC implies that cross-border flows grow faster than the number of the counterparties of a country.

Credit boom and capital inflow periods: These periods are used to define excessive liquidity periods. To identify credit boom periods, we apply Hodrick-Prescott (HP) filter to the percentage growth rate of private-credits-to-GDP ratio ${ }^{8}$ and obtain de-trended series for each country and each year. If the de-trended series in a year for a country is one standard deviation above its country related historical average, that year is assumed to be a credit boom period for that country, as in Fielding and Rewilak (2015) and Caballero (2014). The credit boom dummy variable (CreditBoom $i t)$ takes the value of 1 in country i, at time $t$ for credit boom periods, and 0 otherwise.

\footnotetext{
${ }^{4}$ Lo Duca et al. (2017) propose two approaches regarding the end date of the crisis; end of crisis management date and system back to normal date. The former one points out the end of the acute phase of the crisis and does not include post-crisis adjustment period. We adopt the second approach to become more conservative in our crisis definition, as systemic risk may increase during the adjustment period and countries may experience another crisis.

${ }^{5}$ Lo Duca et al. (2017) specify the systemic crisis dates for the European countries as follows: Belgium (2008-2016), Switzerland (1991-1994; 2010-2016) Germany (2001-2004; 2007-2016), Denmark (1987-1994; 2008-2013), Finland (1991-1998), France (1991-1999; 2008-2016), United Kingdom (1991-1994; 2007-2016), Ireland (2008-2016), Luxembourg (2008-2016), Netherlands (2008-2016), and Sweden (1991-1997; 2008-2016). According to Laeven and Valencia (2013), the crisis dates for Japan is the period of 1997-2001, and for US it is 1988 and the period of 2007-2011.Although we use the systemic crisis dates suggested by the European Systemic Risk Board for European countries, we also estimate the models by using the banking crisis dates suggested by Laeven and Valencia (2013) for all countries in the sample. The results are discussed in the Robustness Tests section in detail.

${ }^{6}$ For technical definitions and detailed discussions of connectivity measures and other network statistics, see Appendix B.

${ }^{7} \mathrm{BCC}$ takes into account the direction of linkages across countries with given flow patterns, as shown in the figure below.
}

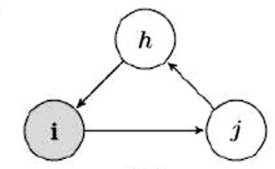

b

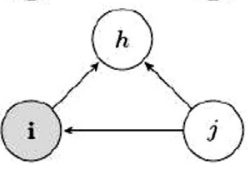

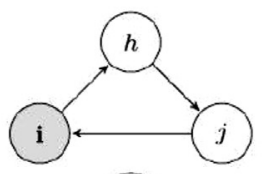

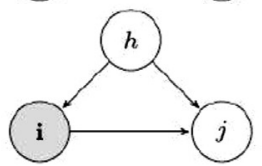

c

d

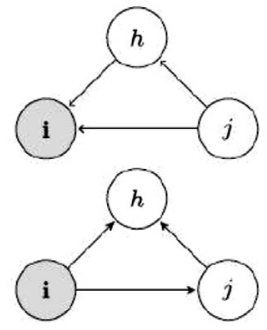

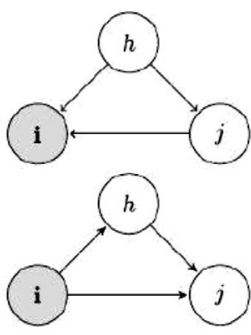

Source: Tabak et al., 2014.

(See above-mentioned references for further information.)

8 Private-credits-to-GDP is defined as a ratio of loans provided to the private sector by domestic money banks to GDP. Using the ratio of private-credit-toGDP, instead of the level of private credits, allows us to correct for pro-cyclical bank lending because the level of private credits is adjusted with the size of the economy. 
Capital inflow dates during the 1978-2008 period are taken from Reinhart and Reinhart (2008). The method proposed by Caballero (2014) and Fielding and Rewilak (2015) is used to identify those dates for the rest of the sample. Using HP filter, we obtain the de-trended series of the ratio of foreign direct investment-to-GDP for each country and the year. If the de-trended series in a year for a country is one standard deviation above its country related historical average, that year is assumed to be a capital inflow period for that country. Capital inflow dummy variable (CapitalInflow $w_{i t}$ ) takes the value of 1 in country i, at time $\mathrm{t}$ for capital inflow periods, and 0 otherwise.

Control variables: The control variables are macroeconomic indicators that are widely used in the literature to examine the probability of crisis (see for example, Demirguc-Kunt and Detragiache, 1998; Demirgüç-Kunt and Detragiache, 2005; Minoiu et al., 2015). They include ${ }^{9}$ real GDP per capita, real effective exchange rate, private credit-to-GDP ratio, current account balanceto-GDP ratio, M3 money-to-GDP ratio, and unemployment rate. As suggested by Tonzer (2015), we also include the HerfindahlHirschman banking sector concentration index (HHI) in the model. It is measured as the summation of the squared value of the lenders' share in borrower country's total inflows, calculated separately for each borrower country in each network. In order to control for any other unobserved, time-invariant, country specific factors that may affect probability of crisis, we incorporate country fixed effects into the model. All of the significant lagged values of macroeconomic variables are included in the model.

\subsection{Data}

International banking flows from banks to banks and from banks to non-banks are defined as exchange rate adjusted flows in cross-border bank claims, from banks located in a particular country to another country in the sample. These flows include loans and deposits, debt securities, and other assets. Flows between any two countries correspond to either an increase or a decrease in cross-border assets of a reporting country with respect to another country. In the analysis, following Minoiu and Reyes (2013), we consider only positive flows and replace negative flows with zeros because positive flows are net investments (i.e. investments minus repayments) whereas negative flows are net repayments. We sum the exchange rate adjusted changes of the four quarters to obtain annualized cross-border flows. Those flows are expressed in terms of constant 2016 US dollars.

Cross-border flows are obtained from BIS Locational Banking Statistics (LBS). ${ }^{10}$ Following the balance of payments approach, LBS is collected on a residency basis. Cross-border exposures are reported based on the location (i.e. residency) of the reporting bank, regardless of their owners' nationality. In this respect, LBS covers the cross-border positions of all banks domiciled in the reporting area, including positions vis-a-vis their foreign affiliates.

In BIS international banking statistics, bilateral cross-border balance sheet positions of all individual banks from reporting countries are aggregated by bank, but they are disaggregated by the recipient country so that we can distinguish lender and borrower countries. The source of funds is the banking sector, whereas the recipient of funds can either be the banking sector or non-banking sector. The recipients of funds are used in identifying BB and BNB networks. The banking sector is composed of deposit money banks, offices controlled by the same banking group (subsidiaries and branches), and central banks. The non-bank sector includes non-bank financial corporations such as hedge funds, securities brokers, money market funds, pension funds, insurance companies, central clearing counterparties, development banks and other financial entities, nonfinancial corporations, government entities, households and general government (public sector) ${ }^{11} \mathrm{HHI}$ is calculated by using BIS data. All of the macroeconomic variables and series used to estimate credit boom and capital inflow dummy variables are obtained from the World Bank World Development Indicators and World Bank Global Financial Development Database.

\section{Characteristics of the BB and the BNB lending networks}

\subsection{Connectivity measures}

Before presenting the empirical findings about the relationship between financial connectivity and the probability of crisis, descriptive statistics of the characteristics of BB and BNB lending networks are presented in Table 1 for the period of 1978-2016, as well as for crisis, non-crisis, credit boom, and capital inflow periods.

The average global connectivity in BB lending network, that's the probability that any two countries in the network are connected; is 58 percent during the sample period. The average local connectivity measured by BCC; the probability that any two counterparties of a country are also counterparties of themselves; is 60 percent. The BNB network is less connected than

\footnotetext{
${ }^{9}$ Descriptive statistics of all variables used in the estimations are presented in Table A.9 at Appendix A.

10 BIS also reports international banking statistics on a consolidated basis (CBS). CBS captures the consolidated positions of banks worldwide offices, including the positions of banks foreign subsidiaries and branches, but excluding inter-office activity with respect to the counterparty country. Hence, in CBS, unlike LBS, it is the nationality of the reporting bank that matters, not the residency. Similar to Minoiu and Reyes (2013), Minoiu et al. (2015), Tonzer (2015) and KalemliOzcan et al. (2013), we use LBS, rather than CBS for the following reasons: (i) Since LBS follows balance of payments principle, it is possible to use and to compare cross-border bank capital flows with any other type of capital flows; (ii) LBS has a longer time coverage than CBS; (iii) LBS provides exchange rate adjusted flow data, as well as stock data whereas CBS provides only stock data. For more information regarding BIS consolidated and locational banking statistics, see McGuire and Wooldridge (2005).

11 Cross-border loans provided by non-bank institutions are not included in BIS dataset.
} 
Table 1

Descriptive network statistics. This table shows the descriptive statistics of the network characteristics for the bank-to-bank lending network in Panel A and bank-to-non-bank lending network in Panel B, during the overall and the selected periods. In-(out-) degree represents the total number of a country's creditors (debtors), whereas in-(out-) strength refers to a country's total cross-border liabilities (exposures). Indirect spillover effects (i.e. financial linkages established by a country's counterparties) are captured by ANND and ANNS measures. For example, ANND(out-out) refers to the number of creditors of a creditor country while ANNS(out-out) refers to the volume representation of ANND(out-out). Definitions of other network characteristics are provided at Appendix B. The strength figures are expressed in terms of constant 2016 bn USD.

\begin{tabular}{|c|c|c|c|c|c|c|c|c|c|c|c|}
\hline & & \multicolumn{2}{|c|}{ Overall Period } & \multicolumn{2}{|c|}{ Crisis Periods } & \multicolumn{2}{|c|}{$\begin{array}{l}\text { Non-Crisis } \\
\text { Periods }\end{array}$} & \multicolumn{2}{|c|}{ Credit Booms } & \multicolumn{2}{|c|}{$\begin{array}{l}\text { Capital } \\
\text { Inflows }\end{array}$} \\
\hline & & Mean & $\begin{array}{l}\text { Std } \\
\text { Dev }\end{array}$ & Mean & $\begin{array}{l}\text { Std } \\
\text { Dev }\end{array}$ & Mean & $\begin{array}{l}\text { Std } \\
\text { Dev }\end{array}$ & Mean & $\begin{array}{l}\text { Std } \\
\text { Dev }\end{array}$ & Mean & $\begin{array}{l}\text { Std } \\
\text { Dev }\end{array}$ \\
\hline \multicolumn{12}{|c|}{ Panel A: Bank-to-Bank Lending } \\
\hline & $\begin{array}{l}\text { Connectivity } \\
\text { Measures }\end{array}$ & & & & & & & & & & \\
\hline & FC & 0.58 & 0.11 & 0.56 & 0.12 & 0.62 & 0.07 & 0.61 & 0.11 & 0.56 & 0.10 \\
\hline & $\mathrm{BCC}$ & 0.60 & 0.12 & 0.52 & 0.13 & 0.63 & 0.10 & 0.62 & 0.15 & 0.58 & 0.13 \\
\hline & WCC & 0.81 & 0.11 & 0.74 & 0.12 & 0.84 & 0.09 & 0.81 & 0.13 & 0.80 & 0.12 \\
\hline & First Order Statistics & & & & & & & & & & \\
\hline & In-Degree & 7.0 & 2.5 & 5.6 & 2.3 & 7.5 & 2.3 & 6.7 & 2.6 & 7.1 & 2.6 \\
\hline & Out-Degree & 7.0 & 2.5 & 5.8 & 2.2 & 7.4 & 2.4 & 7.4 & 2.9 & 6.7 & 2.6 \\
\hline & In-Strength & 46.1 & 70.3 & 45.1 & 82.9 & 46.5 & 64.8 & 53.4 & 60.0 & 73.5 & 136.9 \\
\hline & Out-Strength & 46.1 & 66.1 & 51.5 & 79.2 & 44.1 & 60.2 & 52.2 & 76.7 & 71.4 & 114.1 \\
\hline & HHI & 0.38 & 0.19 & 0.44 & 0.21 & 0.36 & 0.18 & 0.41 & 0.21 & 0.36 & 0.19 \\
\hline & Second Order & & & & & & & & & & \\
\hline & Statistics & & & & & & & & & & \\
\hline & ANND (in-in) & 7.0 & 1.5 & 6.0 & 1.5 & 7.4 & 1.2 & 7.1 & 1.9 & 6.9 & 1.5 \\
\hline & ANND (in-out) & 7.7 & 1.4 & 6.6 & 1.5 & 8.1 & 1.1 & 7.7 & 1.6 & 7.5 & 1.5 \\
\hline & ANND (out-out) & 7.0 & 1.4 & 6.0 & 1.4 & 7.4 & 1.3 & 7.2 & 1.6 & 6.9 & 1.6 \\
\hline & ANND (out-in) & 7.7 & 1.4 & 6.6 & 1.5 & 8.0 & 1.1 & 7.8 & 1.5 & 7.4 & 1.5 \\
\hline & ANNS (in-in) & 49.6 & 41.1 & 45.6 & 31.1 & 51.2 & 44.2 & 55.7 & 43.9 & 50.0 & 43.5 \\
\hline & ANNS (in-out) & 52.3 & 40.7 & 49.0 & 32.5 & 53.6 & 43.3 & 60.0 & 42.3 & 51.2 & 44.3 \\
\hline & ANNS (out-out) & 47.9 & 38.8 & 44.4 & 29.0 & 49.3 & 41.9 & 54.4 & 42.2 & 48.1 & 42.0 \\
\hline & ANNS (out-in) & 51.2 & 41.0 & 50.1 & 30.4 & 51.6 & 44.5 & 58.1 & 49.4 & 52.0 & 47.3 \\
\hline \multirow{2}{*}{\multicolumn{12}{|c|}{$\begin{array}{l}\text { Panel B: Bank-to-Non-Bank } \\
\text { Lending }\end{array}$}} \\
\hline & & & & & & & & & & & \\
\hline & Measures & & & & & & & & & & \\
\hline & $F C$ & 0.54 & 0.09 & 0.53 & 0.09 & 0.54 & 0.09 & 0.56 & 0.09 & 0.53 & 0.06 \\
\hline & $B C C$ & 0.57 & 0.11 & 0.51 & 0.11 & 0.59 & 0.10 & 0.57 & 0.11 & 0.58 & 0.11 \\
\hline & WCC & 0.81 & 0.11 & 0.76 & 0.13 & 0.82 & 0.09 & 0.81 & 0.09 & 0.83 & 0.10 \\
\hline & First Order Statistics & & & & & & & & & & \\
\hline & In-Degree & 6.4 & 2.1 & 5.8 & 2.0 & 6.7 & 2.2 & 6.7 & 2.7 & 6.9 & 2.1 \\
\hline & Out-Degree & 7.0 & 2.5 & 6.1 & 2.4 & 7.3 & 2.4 & 7.3 & 2.3 & 6.8 & 2.5 \\
\hline & In-Strength & 21.5 & 41.8 & 23.8 & 34.4 & 20.6 & 44.2 & 23.8 & 45.4 & 44.3 & 84.1 \\
\hline & Out-Strength & 23.4 & 46.0 & 25.8 & 46.9 & 22.5 & 45.6 & 20.2 & 23.9 & 38.9 & 86.9 \\
\hline & $H H I$ & 0.39 & 0.17 & 0.41 & 0.18 & 0.38 & 0.16 & 0.39 & 0.18 & 0.38 & 0.17 \\
\hline & Second Order & & & & & & & & & & \\
\hline & Statistics & & & & & & & & & & \\
\hline & ANND (in-in) & 6.4 & 1.2 & 5.7 & 1.1 & 6.6 & 1.2 & 6.4 & 1.4 & 6.3 & 1.3 \\
\hline & ANND (in-out) & 7.8 & 1.1 & 7.2 & 1.1 & 8.1 & 1.0 & 7.8 & 1.3 & 7.8 & 1.1 \\
\hline & ANND (out-out) & 6.4 & 1.4 & 5.8 & 1.3 & 6.6 & 1.3 & 6.5 & 1.6 & 6.6 & 1.5 \\
\hline & ANND (out-in) & 7.1 & 1.1 & 6.4 & 1.0 & 7.3 & 1.1 & 7.1 & 1.1 & 6.9 & 1.2 \\
\hline & ANNS (in-in) & 20.6 & 22.2 & 23.2 & 18.0 & 19.6 & 23.6 & 18.5 & 19.8 & 19.8 & 22.1 \\
\hline & ANNS (in-out) & 27.2 & 26.1 & 31.1 & 19.1 & 25.8 & 28.1 & 24.2 & 24.1 & 26.4 & 26.4 \\
\hline & ANNS (out-out) & 22.7 & 23.0 & 24.4 & 16.3 & 22.1 & 25.1 & 22.3 & 22.3 & 24.3 & 25.6 \\
\hline & ANNS (out-in) & 23.6 & 22.1 & 26.1 & 18.0 & 22.7 & 23.4 & 23.0 & 21.8 & 21.8 & 21.1 \\
\hline
\end{tabular}

the BB network. Those figures are 54 percent and 57 percent, respectively in the BNB network. Connectivity measured by WCC rises up to 81 percent in both networks. This reflects the intensity of cross-border lending relationships among countries. On average, the highest levels of connectivity measures are observed in non-crisis periods in both networks, whereas the lowest levels are observed in crisis periods.

\subsection{Other network characteristics}

In addition to connectivity measures, several characteristics of the cross-border BB and BNB lending networks are presented in Table 1. These measures include in- and out-degree, in- and out-strength, average-nearest-neighborhood degree (ANND), and average-nearest-neighborhood strength (ANNS). 
The number of lending relationships across countries is measured by in- and out-degree statistics. We observe that in the BB network, countries borrowed from (lent to), on average, 7.5 (7.4) countries in non-crisis periods, whereas countries reduced the number of countries that they have borrowing (lending) relationship to 5.6 (5.8) in crisis periods. Similarly, in the BNB network, countries borrowed from (lent to), on average, 6.7 (7.3) countries in non-crisis periods whereas the figure reduced to 5.8 (6.1) during crisis periods. In both networks, the highest number of lending relationships was attained in non-crisis periods.

Strength measures indicate the amount of lending relationship across countries. We observe that during the overall analysis period, average cross-border flows borrowed/lent across BB network (in- and out-strength statistics) is almost two times that of the BNB network, although there were, on average, a similar number of creditors (debtors) in both networks (in- and out-degree statistics). The highest amount of average cross-border flows are observed at capital inflow periods in both networks. In particular, average cross-border flows received by the non-banking sector increased by 23.7 bn USD (from 20.6 bn USD to 44.3 bn USD) and those received by banking sector increased by 27 bn USD (from 46.5 bn USD to 73.5 bn USD) during capital inflow periods in comparison to non-crisis periods.

In the BNB network, we observe less fluctuation and lower amount of transactions. For example, countries borrowed from (lent to), on average, 21.5 bn USD (23.4 bn USD) during the overall analysis period. Those figures were 23.8 bn USD (25.8 bn USD) in crisis periods, 23.8 bn USD (20.2 bn USD) in credit booms, but increased to 44.3 bn USD (38.9 bn USD) in capital inflow periods. Cross-border flows are found to be more volatile during capital inflow periods in both networks, as observed by high standard deviations of the in- (out-) strength measures. ${ }^{12}$ Our findings also show that in the BNB network, average cross-border flows borrowed from (lent to) increased from 20.6 bn USD (22.5 bn USD) in non-crisis periods to 23.8 bn USD ( 25.8 bn USD) in crisis periods. Similarly, in the BB lending network, average cross-border flows lent is increased from 44.1 bn USD in non-crisis periods to 51.5 bn USD in crisis periods.

The second-order statistics support the previous finding that the average connectivity in both networks declined during the crisis periods. For example, in the BB network, ANND (in-in) measure suggests that debtors of a debtor country received funding from, on average, 7.4 countries in non-crisis periods, but from only 6 countries in crisis periods. Similarly, the ANND (in-out) figure suggests that debtors of a creditor country received funding from, on average, 8.1 countries in non-crisis periods and 6.6 countries in crisis periods. In the BB network, average second order cross-border flows were highest in credit boom periods, and lowest at crisis periods, whereas in the BNB lending network, the flows were highest in crisis periods. For example, in BB network, the average ANNS (in-out) indicates that debtors of a creditor country received, on average, 60 bn USD in credit boom periods, but the figure declined to 49 bn USD in crisis periods. In BNB network, this figure was 24.2 bn USD in credit boom periods and reached to 31.1 bn USD in crisis periods. These values suggest that banks may prefer non-bank borrowers to bank borrowers during crisis periods.

In addition, we examine how both networks evolve during the pre- and the post-GFC periods. According to Fig. 1, that illustrates the BB and BNB lending networks in the pre- and the post-GFC periods, BNB lending network seems closer to a complete network where all countries are connected with each other and denser than the BB lending network in the post-GFC. This suggests that the BNB lending network was less severely affected by the recent GFC. These differences between networks may be explained by a funding shift from bank borrowers towards non-bank borrowers during crisis periods, as supported by the network statistics reported in Table 1. In particular, the non-bank sector received, on average, 23.8 bn USD cross-border flows (in-strength) in both credit boom and crisis periods, while the average cross-border flows received by the banking sector decreased from 53.4 bn USD in credit boom to 45.1 bn USD in crisis periods. Analysis of the second-order cross-border flows also points out the same finding, as discussed previously.

\subsection{Country differences}

Fig. 2 and 3 show connectivity measures (BCC and WCC) and real cross-border lending flows (out-strength) of each country during the 1978-2016 period in the BB and BNB lending networks, respectively. Countries have similar characteristics. First, cross-border flows and connectivity measures in both networks decreased considerably when the GFC hit a country, but tend to increase afterwards. Second, countries experienced fluctuations in their cross-border flows and connectivity level. Third, gradual declines in the connectivity level are observed during the early 1980s and the early 1990s, corresponding to global recession periods. Finally, the BNB lending network seem to be more stable in terms of the number and the amount of lending relationships and recovered from the GFC faster than the BB lending network, because following the GFC, in BNB lending network the level of connectivity and the volume of cross-border flows across countries have reached almost to their pre-crisis levels in almost all countries. For example, cross-border flows to banking sector in France declined from 198 bn USD in 2007 to 53 bn USD in 2008; while connectivity measured by BCC reduced by 48 percentage points. On the other hand, cross-border flows to the non-banking sector in France increased from 91 bn USD in 2007 to 97 bn USD in 2008 and connectivity measured by BCC drops only 25 percentage points. We observe similar trends in Sweden, Denmark and Belgium. Similarly, cross-border flows to non-banking sector in the US reached its pre-GFC level in 2016 . However, annual flows to the banking sector were still around one-fifth of its pre-GFC level during the aftermath of GFC.

\footnotetext{
12 The reason of higher volatility could be attributed to the large amount of cross-border flows to and from UK, US, France, and Germany during the 2005-2007 period.
} 


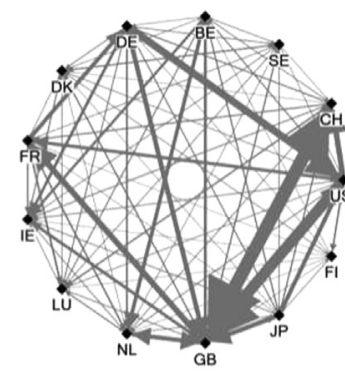

2007

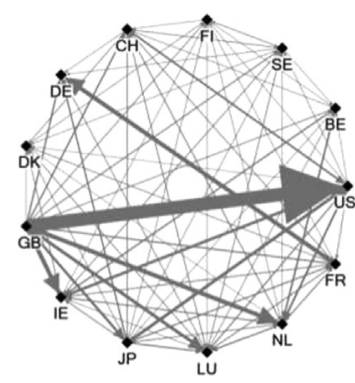

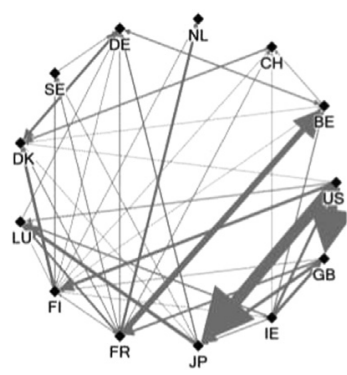

2009

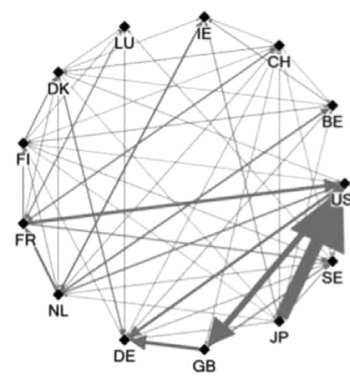

Fig. 1. Bank-to-Bank and Bank-to-Non-Bank Lending Networks in 2007 and 2009. Notes: This figure shows bank-to-bank (upper panel) and bank-to-nonbank (lower panel) lending network in the year 2007 (left-hand-side) and the 2009 (right-hand-side). The countries represent nodes and the links between nodes represent cross-border banking flows (expressed in constant 2016 USD). Thicker links indicate larger flows. Arrows indicate the direction of the flows. Data sources: BIS bilateral locational banking statistics.

Motivated by those findings, in the next section, we examine the relationship between financial connectivity and the probability of systemic crisis, controlling for macroeconomic characteristics, and explore how this relationship changes in credit boom and capital inflow periods.

\section{Regression results}

\subsection{The relationship between financial connectivity and financial stability}

Tables 2 and 3 show the results of the probit model with country fixed effects which investigates the relationship between financial connectivity and probability of crisis, controlling for macroeconomic characteristics and credit boom and capital inflow periods, respectively. In each table, Panels A and B show the results for the BB and the BNB lending networks, respectively. Columns with odd-numbers $(1,3,5,7,9,11)$ show the estimations with contemporaneous connectivity measure and dummy variable (CreditBoom or CapitalInflow). The models estimated with one period lagged values of these variables are reported in columns with even-numbers $(2,4,6,8,10,12)$. For macroeconomic variables, all significant lags are controlled in the models. In all of the models, the dependent variable is a crisis dummy variable.

We find that for both networks, the coefficients of connectivity measures are statistically significant and negative in contemporaneous models, regardless of the measure used for connectivity. The results imply that as financial connectivity increases, probability of crisis decreases in the countries analyzed. When we estimate the models with lagged connectivity measures and the dummy variables, connectivity coefficient is found to be negative and significant only for BB network and with global connectivity measure, controlling for credit boom periods or capital inflow periods. ${ }^{13}$ The findings support the theory of Allen and Gale (2000) and the empirical results of Chinazzi et al. (2013) and Tonzer (2015) who shows that in stable times increased level of financial linkages across countries improves financial stability by transferring positive spillover effects. Unlike them, Minoiu et al. (2015) find a positive relationship between the probability of crisis and the level of connectivity in the previous year. The difference in findings can be explained by their definition of crisis. The authors define one year before the actual crisis year as a crisis year and exclude the subsequent four years after the crisis. They claim that countries often have limited access to international capital markets during the crisis period. ${ }^{14}$ However, as reported in Figs. 2 and 3, even though there was a decline in cross-border flows one year after the crisis, this pattern in flows was not observed for four years.

\footnotetext{
${ }^{13}$ We re-estimate the credit boom and capital inflow models to test for endogeneity among the connectivity measure and the other regressors. The result favors absence of endogeneity. In particular, the Wald test of the exogeneity of the instrumented variables does not reject the null hypothesis of there is no endogeneity.

${ }^{14}$ Unlike Minoiu et al. (2015), we include the entire crisis period in our analysis. Moreover, their connectivity measure is obtained by using principal component analysis of all network characteristics, including in- and out-degree and strength measures and their second-order nearest neighborhood statistics.
} 

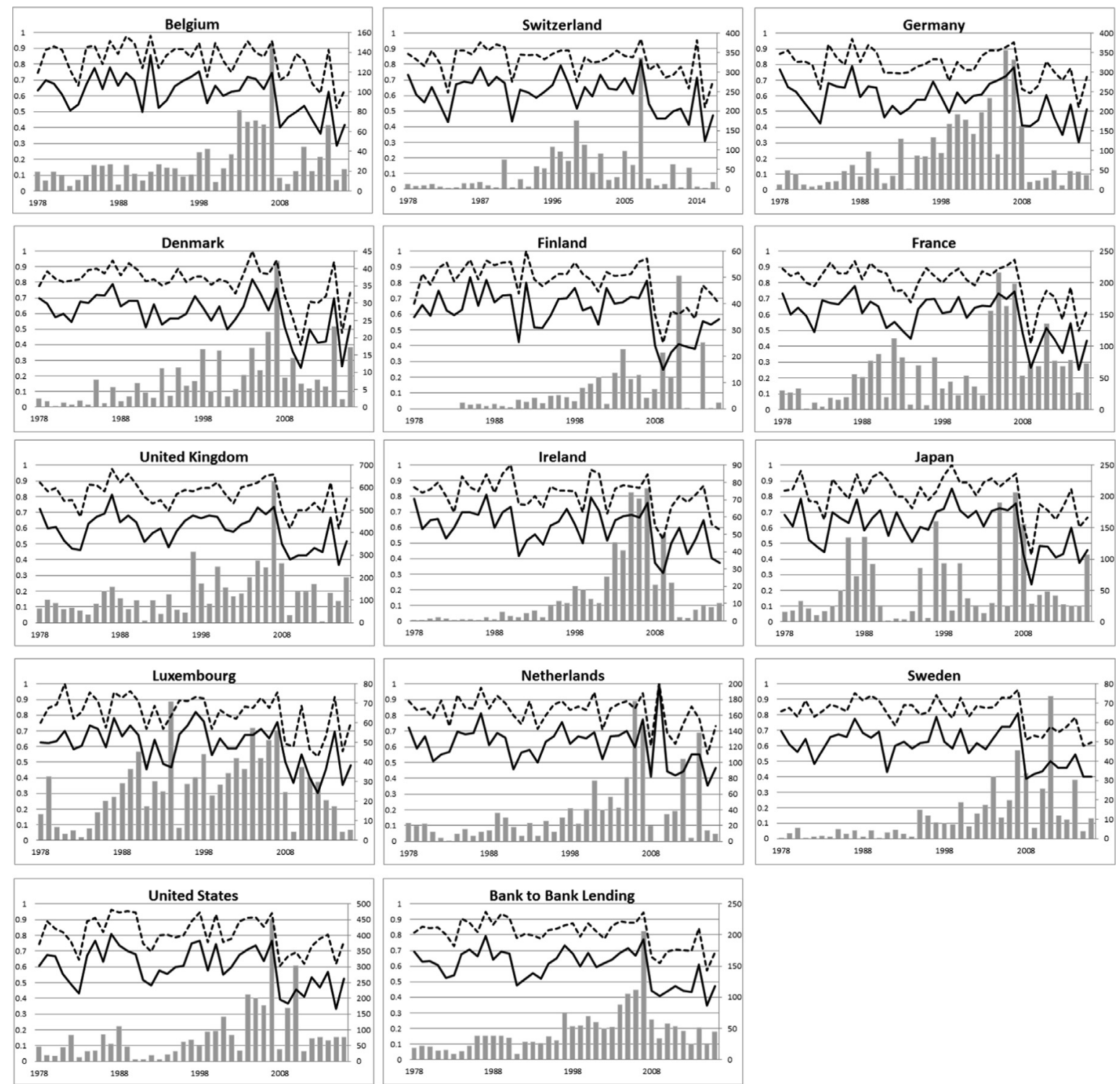

Fig. 2. Financial Connectivity and International Bank Flows, Bank-to-Bank Lending. Notes: In each figure the right-axis indicates the volume of cross-border loans (i.e. out-strength) provided by banks to the banking sector in constant 2016 bn USD and left-axis indicates financial connectivity meaures. The solid and the dashed lines represent BCC and WCC measures, respectively. The figure for bank-to-bank lending presents the average for all countries in the sample. Data source is BIS bilateral locational banking statistics.

\subsubsection{Credit boom periods}

We test whether the observed negative relationship between financial connectivity and probability of crisis changes in credit boom periods by including in the model an interaction variable between connectivity measure and the dummy variable indicating credit boom periods. Table 4 shows the results of the probit model. In the BB network, we find statistically significant and positive coefficients of interaction variables. They imply that the negative relationship observed between the financial connectivity and the probability of crisis is mitigated (Model 1) and even completely eliminated (Models 3, 4, and 5) in credit boom periods. Hence, one may argue that an increase in financial connectivity rises the probability of crisis by facilitating negative spillover effects through increased liquidity in credit boom periods. The coefficients of interaction variables are found to be smaller when the lagged connectivity measure is used in the analysis than the case when the current level is used. It suggests that short-term effect of credit booms on the probability of crisis is more pronounced than its long-term effect in the BB lending network. The magnitude of this effect seems to change with the measure of connectivity. The coefficients of interaction variables for local connectivity measures BCC and WCC in contemporaneous models are higher than that of FC. The highest coefficient is observed when connectivity is measured by WCC, an indicator that accounts for both the number and the amount of lending relationships that a country establishes. 

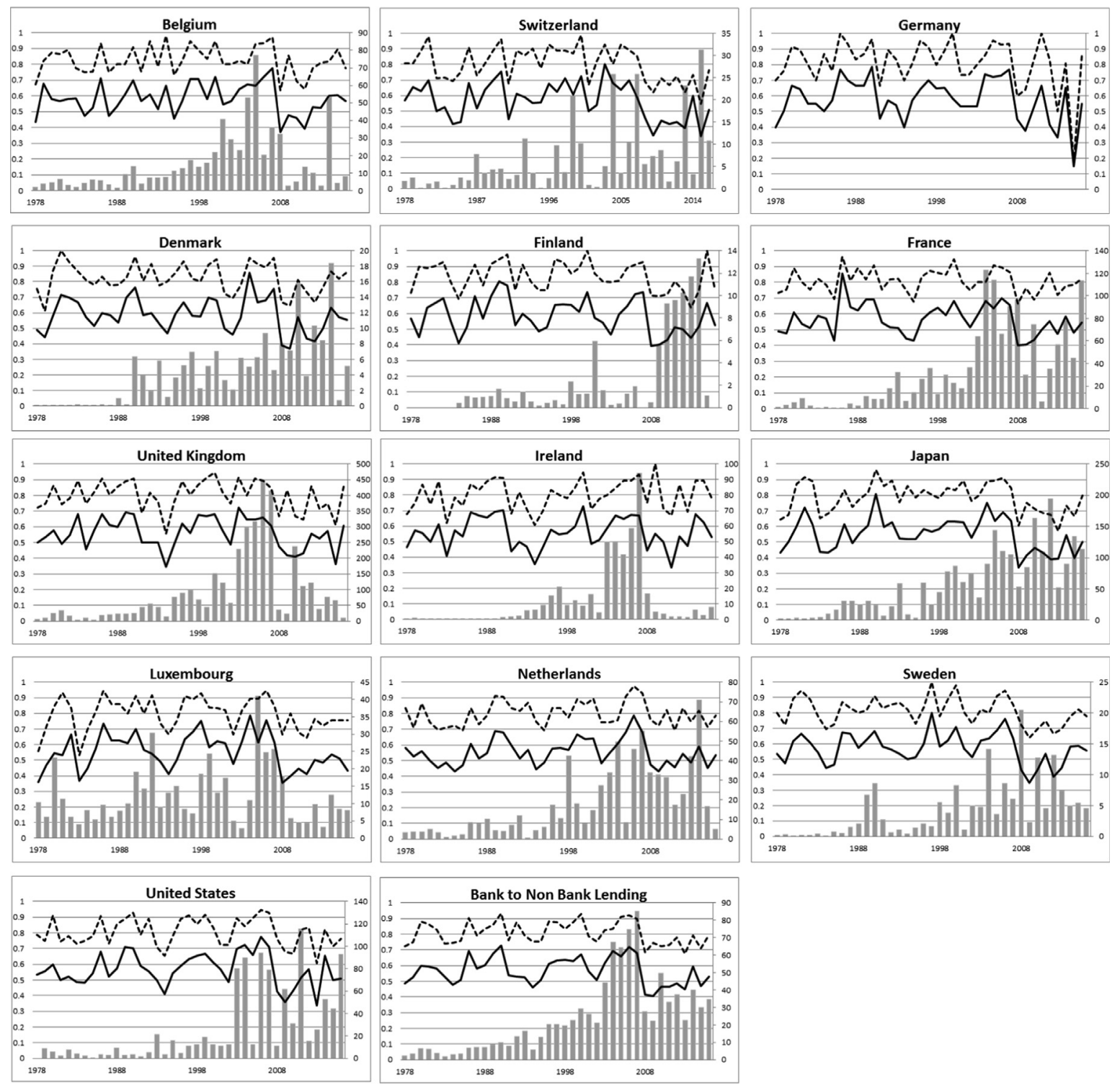

Fig. 3. Financial Connectivity and International Bank Flows, Bank-to-Non-Bank Lending. Notes: In each figure the right-axis indicates the volume of crossborder loans (i.e. out-strength) provided by banks to the non-banking sector in constant 2016 bn USD and left-axis indicates financial connectivity measures. The solid and the dashed lines represent BCC and WCC measures, respectively. Since cross-border loans provided to the non-banking sector of Germany is not publicly available, WCC measure for this country is calculated by using the "in" type of borrowing relationships only. The figure for bank-tonon-bank lending presents the average for all countries in the sample. Data source is BIS bilateral locational banking statistics.

Panel B of Table 4 shows the results for the BNB lending network. We find that an increase in the level of financial connectivity reduces the probability of crisis in contemporaneous models. The findings are similar when connectivity is measured both globally and locally. However, unlike the BB network, the coefficients of interaction variables in the BNB network are statistically insignificant in all models. Those findings indicate that credit boom periods do not significantly change the relationship between connectivity and probability of crisis in the BNB lending network. It is an expected result because cross-border flows to the non-bank sector are channeled into real economy, and may not lead to immediate destabilization. The insignificant coefficients of the credit boom dummy variable in models for the BNB lending network indicate that non-bank borrowers are less sensitive to credit booms, as we conclude by the first and the second-order degree and strength statistics of this network, reported in Table 1. Almost all of the control variables are statistically significant and have expected signs in both networks.

\subsubsection{Capital inflow periods}

Table 5 presents the results of the probit model that examines how the relationship between connectivity and probability of crisis changes in capital inflow periods. In the BB lending network (panel A), a negative relationship between connectivity 
Table 2

Results of the probit models controlling for credit boom periods. This table presents the estimated coefficients of probit models with country fixed effects. The p-values are in parentheses. The dependent variable is a dummy variable taking a value of 1 in crisis periods, and 0 otherwise and CreditBoom is a dummy variable taking a value of 1 in credit boom periods, and 0 otherwise. Definitions of other variables are provided at the Table A.8 in the appendix A. Panels A and $B$ report the findings for the bank-to-bank and the bank-to-non-bank lending networks, respectively. The models reported in columns with odd-numbers $(1,3,5,7,9,11)$ are contemporaneous models and those reported in columns with even numbers $(2,4,6,8,10,12)$ are lagged models including one period lagged values of connectivity measures and CreditBoom dummy variable. All of the significant lagged values of macroeconomic control variables are included in the models.

\begin{tabular}{|c|c|c|c|c|c|c|c|c|c|c|c|c|}
\hline & \multicolumn{6}{|c|}{ Panel A: Bank-to-Bank Lending } & \multicolumn{6}{|c|}{ Panel B: Bank-to-Non-Bank Lending } \\
\hline & $(1)$ & $(2)$ & (3) & $(4)$ & $(5)$ & $(6)$ & $(7)$ & $(8)$ & $(9)$ & $(10)$ & $(11)$ & $(12)$ \\
\hline \multicolumn{13}{|c|}{ Connectivity Measure } \\
\hline $\operatorname{Ln}(F C)$ & $\begin{array}{l}-2.262 \\
(0.000)\end{array}$ & $\begin{array}{c}-0.971 \\
(0.044)\end{array}$ & & & & & $\begin{array}{l}-2.653 \\
(0.000)\end{array}$ & $\begin{array}{c}-0.101 \\
(0.199)\end{array}$ & & & & \\
\hline $\operatorname{Ln}(B C C)$ & & & $\begin{array}{l}-1.472 \\
(0.000)\end{array}$ & $\begin{array}{l}-0.394 \\
(0.328)\end{array}$ & & & & & $\begin{array}{r}-1.458 \\
(0.002)\end{array}$ & $\begin{array}{c}-0.570 \\
(0.221)\end{array}$ & & \\
\hline $\operatorname{Ln}(W C C)$ & & & & & $\begin{array}{l}-1.783 \\
(0.005)\end{array}$ & $\begin{array}{l}-0.190 \\
(0.766)\end{array}$ & & & & & $\begin{array}{l}-2.796 \\
(0.000)\end{array}$ & $\begin{array}{l}-0.731 \\
(0.342)\end{array}$ \\
\hline \multicolumn{13}{|l|}{ Control Variables } \\
\hline CreditBoom & $\begin{array}{c}0.483 \\
(0.100)\end{array}$ & $\begin{array}{c}0.330 \\
(0.249)\end{array}$ & $\begin{array}{c}0.457 \\
(0.100)\end{array}$ & $\begin{array}{c}0.364 \\
(0.201)\end{array}$ & $\begin{array}{c}0.421 \\
(0.139)\end{array}$ & $\begin{array}{c}0.357 \\
(0.212)\end{array}$ & $\begin{array}{c}0.428 \\
(0.155)\end{array}$ & $\begin{array}{c}0.263 \\
(0.366)\end{array}$ & $\begin{array}{c}0.429 \\
(0.145)\end{array}$ & $\begin{array}{c}0.241 \\
(0.407)\end{array}$ & $\begin{array}{c}0.464 \\
(0.117)\end{array}$ & $\begin{array}{c}0.259 \\
(0.371)\end{array}$ \\
\hline $\operatorname{Ln}(\text { GDPpercapita })_{t}$ & $\begin{array}{c}5.335 \\
(0.000)\end{array}$ & $\begin{array}{c}5.499 \\
(0.000)\end{array}$ & $\begin{array}{c}5.713 \\
(0.000)\end{array}$ & $\begin{array}{c}5.791 \\
(0.000)\end{array}$ & $\begin{array}{c}5.649 \\
(0.000)\end{array}$ & $\begin{array}{c}5.922 \\
(0.000)\end{array}$ & $\begin{array}{c}5.574 \\
(0.000)\end{array}$ & $\begin{array}{c}5.686 \\
(0.000)\end{array}$ & $\begin{array}{c}5.719 \\
(0.000)\end{array}$ & $\begin{array}{c}5.555 \\
(0.000)\end{array}$ & $\begin{array}{c}5.818 \\
(0.000)\end{array}$ & $\begin{array}{r}5.620 \\
(0.000)\end{array}$ \\
\hline $\operatorname{Ln}(\text { PrivCredit } / G D P)_{t}$ & $\begin{array}{c}0.631 \\
(0.028)\end{array}$ & $\begin{array}{c}0.796 \\
(0.005)\end{array}$ & $\begin{array}{c}0.645 \\
(0.023)\end{array}$ & $\begin{array}{c}0.759 \\
(0.007)\end{array}$ & $\begin{array}{c}0.701 \\
(0.013)\end{array}$ & $\begin{array}{c}0.764 \\
(0.007)\end{array}$ & $\begin{array}{c}0.705 \\
(0.018)\end{array}$ & $\begin{array}{c}0.846 \\
(0.004)\end{array}$ & $\begin{array}{c}0.771 \\
(0.009)\end{array}$ & $\begin{array}{c}0.839 \\
(0.004)\end{array}$ & $\begin{array}{c}0.809 \\
(0.007)\end{array}$ & $\begin{array}{r}0.835 \\
(0.005)\end{array}$ \\
\hline$H H I_{t}$ & $\begin{array}{c}1.136 \\
(0.056)\end{array}$ & $\begin{array}{c}1.844 \\
(0.001)\end{array}$ & $\begin{array}{c}1.664 \\
(0.003)\end{array}$ & $\begin{array}{c}1.927 \\
(0.000)\end{array}$ & $\begin{array}{c}1.750 \\
(0.001)\end{array}$ & $\begin{array}{c}1.976 \\
(0.000)\end{array}$ & $\begin{array}{c}1.238 \\
(0.073)\end{array}$ & $\begin{array}{c}2.479 \\
(0.000)\end{array}$ & $\begin{array}{c}1.785 \\
(0.006)\end{array}$ & $\begin{array}{c}2.421 \\
(0.000)\end{array}$ & $\begin{array}{c}1.983 \\
(0.001)\end{array}$ & $\begin{array}{r}2.470 \\
(0.000)\end{array}$ \\
\hline$H H I_{t-1}$ & $\begin{array}{c}0.008 \\
(0.989)\end{array}$ & $\begin{array}{c}0.006 \\
(0.992)\end{array}$ & $\begin{array}{c}0.136 \\
(0.812)\end{array}$ & $\begin{array}{c}0.345 \\
(0.538)\end{array}$ & $\begin{array}{c}0.296 \\
(0.595)\end{array}$ & $\begin{array}{c}0.418 \\
(0.454)\end{array}$ & $\begin{array}{c}0.861 \\
(0.174)\end{array}$ & $\begin{array}{c}1.231 \\
(0.066)\end{array}$ & $\begin{array}{c}1.122 \\
(0.078)\end{array}$ & $\begin{array}{c}0.983 \\
(0.115)\end{array}$ & $\begin{array}{c}1.262 \\
(0.047)\end{array}$ & $\begin{array}{c}1.105 \\
(0.066)\end{array}$ \\
\hline$H H I_{t-2}$ & $\begin{array}{c}0.065 \\
(0.909)\end{array}$ & $\begin{array}{c}0.178 \\
(0.751)\end{array}$ & $\begin{array}{c}0.119 \\
(0.833)\end{array}$ & $\begin{array}{c}0.324 \\
(0.558)\end{array}$ & $\begin{array}{c}0.248 \\
(0.654)\end{array}$ & $\begin{array}{c}0.411 \\
(0.452)\end{array}$ & $\begin{array}{c}0.684 \\
(0.288)\end{array}$ & $\begin{array}{c}1.362 \\
(0.034)\end{array}$ & $\begin{array}{c}0.897 \\
(0.164)\end{array}$ & $\begin{array}{c}1.156 \\
(0.071)\end{array}$ & $\begin{array}{c}0.813 \\
(0.212)\end{array}$ & $\begin{array}{c}1.232 \\
(0.051)\end{array}$ \\
\hline$C A B_{t}$ & $\begin{array}{c}0.107 \\
(0.120)\end{array}$ & $\begin{array}{c}0.095 \\
(0.161)\end{array}$ & $\begin{array}{c}0.111 \\
(0.105)\end{array}$ & $\begin{array}{c}0.100 \\
(0.133)\end{array}$ & $\begin{array}{c}0.108 \\
(0.107)\end{array}$ & $\begin{array}{c}0.095 \\
(0.146)\end{array}$ & $\begin{array}{c}0.131 \\
(0.064)\end{array}$ & $\begin{array}{c}0.095 \\
(0.163)\end{array}$ & $\begin{array}{c}0.096 \\
(0.179)\end{array}$ & $\begin{array}{c}0.093 \\
(0.176)\end{array}$ & $\begin{array}{c}0.103 \\
(0.151)\end{array}$ & $\begin{array}{r}0.095 \\
(0.168)\end{array}$ \\
\hline$C A B_{t-1}$ & $\begin{array}{c}-0.244 \\
(0.000)\end{array}$ & $\begin{array}{l}-0.256 \\
(0.000)\end{array}$ & $\begin{array}{l}-0.265 \\
(0.000)\end{array}$ & $\begin{array}{c}-0.267 \\
(0.000)\end{array}$ & $\begin{array}{l}-0.269 \\
(0.000)\end{array}$ & $\begin{array}{l}-0.267 \\
(0.000)\end{array}$ & $\begin{array}{l}-0.271 \\
(0.000)\end{array}$ & $\begin{array}{l}-0.268 \\
(0.000)\end{array}$ & $\begin{array}{l}-0.260 \\
(0.000)\end{array}$ & $\begin{array}{l}-0.262 \\
(0.000)\end{array}$ & $\begin{array}{l}-0.275 \\
(0.000)\end{array}$ & $\begin{array}{l}-0.265 \\
(0.000)\end{array}$ \\
\hline$R E E R_{t}$ & $\begin{array}{c}0.036 \\
(0.005)\end{array}$ & $\begin{array}{c}0.032 \\
(0.008)\end{array}$ & $\begin{array}{c}0.034 \\
(0.007)\end{array}$ & $\begin{array}{c}0.032 \\
(0.009)\end{array}$ & $\begin{array}{c}0.034 \\
(0.007)\end{array}$ & $\begin{array}{c}0.032 \\
(0.010)\end{array}$ & $\begin{array}{c}0.041 \\
(0.001)\end{array}$ & $\begin{array}{c}0.042 \\
(0.001)\end{array}$ & $\begin{array}{c}0.045 \\
(0.001)\end{array}$ & $\begin{array}{c}0.041 \\
(0.001)\end{array}$ & $\begin{array}{c}0.045 \\
(0.001)\end{array}$ & $\begin{array}{c}0.042 \\
(0.001)\end{array}$ \\
\hline$M 3 / G D P_{t}$ & $\begin{array}{l}-0.012 \\
(0.052)\end{array}$ & $\begin{array}{l}-0.015 \\
(0.013)\end{array}$ & $\begin{array}{l}-0.014 \\
(0.021)\end{array}$ & $\begin{array}{l}-0.016 \\
(0.006)\end{array}$ & $\begin{array}{c}-0.014 \\
(0.015)\end{array}$ & $\begin{array}{l}-0.017 \\
(0.004)\end{array}$ & $\begin{array}{l}-0.019 \\
(0.001)\end{array}$ & $\begin{array}{l}-0.023 \\
(0.000)\end{array}$ & $\begin{array}{l}-0.021 \\
(0.000)\end{array}$ & $\begin{array}{l}-0.022 \\
(0.000)\end{array}$ & $\begin{array}{l}-0.023 \\
(0.000)\end{array}$ & $\begin{array}{l}-0.022 \\
(0.000)\end{array}$ \\
\hline Unemployment $_{t}$ & $\begin{array}{c}0.397 \\
(0.000)\end{array}$ & $\begin{array}{c}0.381 \\
(0.000)\end{array}$ & $\begin{array}{c}0.410 \\
(0.000)\end{array}$ & $\begin{array}{c}0.392 \\
(0.000)\end{array}$ & $\begin{array}{c}0.402 \\
(0.000)\end{array}$ & $\begin{array}{c}0.398 \\
(0.000)\end{array}$ & $\begin{array}{c}0.389 \\
(0.000)\end{array}$ & $\begin{array}{c}0.409 \\
(0.000)\end{array}$ & $\begin{array}{c}0.419 \\
(0.000)\end{array}$ & $\begin{array}{c}0.395 \\
(0.000)\end{array}$ & $\begin{array}{c}0.430 \\
(0.000)\end{array}$ & $\begin{array}{c}0.401 \\
(0.000)\end{array}$ \\
\hline Obs. & 427 & 427 & 427 & 427 & 427 & 427 & 427 & 427 & 427 & 427 & 427 & 427 \\
\hline Log-likelihood & -128.4 & -139.0 & -133.2 & -140.6 & -136.2 & -141.0 & -124.1 & -134.7 & -126.2 & -133.9 & -124.9 & -134.2 \\
\hline
\end{tabular}

and the probability of crisis is observed. Coefficient of CapitalInflow dummy variable is found to be positive and statistically significant in lagged models. ${ }^{15}$ The destabilizing impact of capital inflows is also observed by Caballero (2014). He predicts that capital inflow upsurges increase probability of crisis from 4 percent to 14 percent, using 47 crisis periods experienced in 57 countries.

The coefficients of interaction variables between connectivity measures and capital inflow dummy variable are positive and statistically significant in all models and higher than the coefficient of connectivity measures. Hence, the observed negative relationship between financial connectivity and the probability of crisis is eliminated in capital inflow periods. The combined coefficients of connectivity measures $\left(\beta_{1}+\beta_{3}\right)$ imply that an increase in the level of financial connectivity rises the probability of crisis in capital inflow periods in BB lending network.

Panel B of Table 5 shows the results for the BNB lending network. The coefficients of connectivity measures are found to be negative and statistically significant only in the contemporaneous models. Unlike BB network, the coefficient of capital inflow dummy variable is found to be statistically insignificant in all models. The coefficients of interaction variables are positive and significant only in contemporaneous models. The findings suggest that the negative relationship observed between financial connectivity and the probability of crisis is either mitigated (Model 7) or eliminated (Model 9 and 11) in capital inflow periods. However, this effect is limited to short-term in BNB lending market, as suggested by statistically insignificant coefficients of connectivity measures and the interaction variables in lagged models.

Table 6 shows the $\chi^{2}$ test results of the hypothesis that the combined coefficients of connectivity measures $\left(\beta_{1}+\beta_{3}\right)$ in credit boom and capital inflow periods equal to zero. For both networks, almost all of the coefficients are found to be insignificant. The results suggest that in excessive liquidity periods defined by credit boom and capital inflow dummy variables, negative relationship observed between financial connectivity and the probability of crisis disappears.

\footnotetext{
15 The lagged effect of capital inflows is also found in the earlier studies. For example, Kauko (2012) shows that longer lags in capital inflows are needed to predict future difficulties.
} 
Table 3

Results of the probit models controlling for capital inflow periods. This table presents the estimated coefficients of probit models with country fixed effects. The p-values are in parentheses. The dependent variable is a dummy variable taking a value of 1 in crisis periods, and 0 otherwise and Capitalinflow is a dummy variable taking a value of 1 in capital inflow periods, and 0 otherwise. Definitions of other variables are provided at the Table A.8 in the appendix A. Panels A and $B$ report the findings for the bank-to-bank and the bank-to-non-bank lending networks, respectively. The models reported in columns with odd-numbers $(1,3,5,7,9,11)$ are contemporaneous models and those reported in columns with even numbers $(2,4,6,8,10,12)$ are lagged models including one period lagged values of connectivity measures and CapitalInflow dummy variable. All of the significant lagged values of macroeconomic control variables are included in the models.

\begin{tabular}{|c|c|c|c|c|c|c|c|c|c|c|c|c|}
\hline & \multicolumn{6}{|c|}{ Panel A: Bank-to-Bank Lending } & \multicolumn{6}{|c|}{ Panel B: Bank-to-Non-Bank Lending } \\
\hline & $(1)$ & $(2)$ & (3) & $(4)$ & $(5)$ & $(6)$ & $(7)$ & $(8)$ & (9) & $(10)$ & $(11)$ & $(12)$ \\
\hline \multicolumn{13}{|c|}{ Connectivity Measure } \\
\hline $\operatorname{Ln}(F C)$ & $\begin{array}{l}-2.264 \\
(0.000)\end{array}$ & $\begin{array}{l}-1.016 \\
(0.035)\end{array}$ & & & & & $\begin{array}{c}-2.684 \\
(0.000)\end{array}$ & $\begin{array}{c}-0.064 \\
(0.516)\end{array}$ & & & & \\
\hline $\operatorname{Ln}(B C C)$ & & & $\begin{array}{c}-1.489 \\
(0.000)\end{array}$ & $\begin{array}{c}-0.397 \\
(0.329)\end{array}$ & & & & & $\begin{array}{l}-1.476 \\
(0.001)\end{array}$ & $\begin{array}{l}-0.593 \\
(0.202)\end{array}$ & & \\
\hline $\operatorname{Ln}(W C C)$ & & & & & $\begin{array}{l}-1.834 \\
(0.004)\end{array}$ & $\begin{array}{l}-0.238 \\
(0.712)\end{array}$ & & & & & $\begin{array}{l}-2.767 \\
(0.000)\end{array}$ & $\begin{array}{l}-0.742 \\
(0.334)\end{array}$ \\
\hline \multicolumn{13}{|l|}{ Control Variables } \\
\hline CapitalInflow & $\begin{array}{l}-0.413 \\
(0.137)\end{array}$ & $\begin{array}{c}0.165 \\
(0.529)\end{array}$ & $\begin{array}{r}-0.420 \\
(0.129)\end{array}$ & $\begin{array}{c}0.144 \\
(0.582)\end{array}$ & $\begin{array}{c}-0.389 \\
(0.156)\end{array}$ & $\begin{array}{c}0.137 \\
(0.600)\end{array}$ & $\begin{array}{c}-0.474 \\
(0.097)\end{array}$ & $\begin{array}{c}0.093 \\
(0.423)\end{array}$ & $\begin{array}{c}-0.461 \\
(0.099)\end{array}$ & $\begin{array}{c}0.089 \\
(0.534)\end{array}$ & $\begin{array}{l}-0.445 \\
(0.100)\end{array}$ & $\begin{array}{c}0.093 \\
(0.621)\end{array}$ \\
\hline $\operatorname{Ln}(\text { GDPpercapita })_{t}$ & $\begin{array}{c}5.304 \\
(0.000)\end{array}$ & $\begin{array}{c}5.309 \\
(0.000)\end{array}$ & $\begin{array}{c}5.684 \\
(0.000)\end{array}$ & $\begin{array}{c}5.595 \\
(0.000)\end{array}$ & $\begin{array}{c}5.611 \\
(0.000)\end{array}$ & $\begin{array}{c}5.709 \\
(0.000)\end{array}$ & $\begin{array}{c}5.590 \\
(0.000)\end{array}$ & $\begin{array}{c}5.533 \\
(0.000)\end{array}$ & $\begin{array}{c}5.719 \\
(0.000)\end{array}$ & $\begin{array}{c}5.426 \\
(0.000)\end{array}$ & $\begin{array}{c}5.803 \\
(0.000)\end{array}$ & $\begin{array}{c}5.487 \\
(0.000)\end{array}$ \\
\hline $\operatorname{Ln}(\text { Priv Credit } / G D P)_{t}$ & $\begin{array}{c}0.694 \\
(0.014)\end{array}$ & $\begin{array}{c}0.860 \\
(0.002)\end{array}$ & $\begin{array}{c}0.705 \\
(0.012)\end{array}$ & $\begin{array}{c}0.827 \\
(0.003)\end{array}$ & $\begin{array}{c}0.757 \\
(0.006)\end{array}$ & $\begin{array}{c}0.831 \\
(0.003)\end{array}$ & $\begin{array}{c}0.746 \\
(0.010)\end{array}$ & $\begin{array}{c}0.906 \\
(0.002)\end{array}$ & $\begin{array}{c}0.816 \\
(0.005)\end{array}$ & $\begin{array}{c}0.893 \\
(0.002)\end{array}$ & $\begin{array}{c}0.866 \\
(0.003)\end{array}$ & $\begin{array}{c}0.893 \\
(0.002)\end{array}$ \\
\hline$H H I_{t}$ & $\begin{array}{c}1.190 \\
(0.044)\end{array}$ & $\begin{array}{c}1.820 \\
(0.001)\end{array}$ & $\begin{array}{c}1.736 \\
(0.002)\end{array}$ & $\begin{array}{c}1.909 \\
(0.000)\end{array}$ & $\begin{array}{c}1.803 \\
(0.001)\end{array}$ & $\begin{array}{c}1.957 \\
(0.000)\end{array}$ & $\begin{array}{c}1.337 \\
(0.050)\end{array}$ & $\begin{array}{c}2.502 \\
(0.000)\end{array}$ & $\begin{array}{c}1.863 \\
(0.004)\end{array}$ & $\begin{array}{c}2.455 \\
(0.000)\end{array}$ & $\begin{array}{c}2.069 \\
(0.001)\end{array}$ & $\begin{array}{c}2.508 \\
(0.000)\end{array}$ \\
\hline$H H I_{t-1}$ & $\begin{array}{l}-0.096 \\
(0.869)\end{array}$ & $\begin{array}{c}0.005 \\
(0.994)\end{array}$ & $\begin{array}{c}0.047 \\
(0.935)\end{array}$ & $\begin{array}{c}0.375 \\
(0.503)\end{array}$ & $\begin{array}{c}0.209 \\
(0.707)\end{array}$ & $\begin{array}{c}0.438 \\
(0.432)\end{array}$ & $\begin{array}{c}0.720 \\
(0.250)\end{array}$ & $\begin{array}{c}1.177 \\
(0.078)\end{array}$ & $\begin{array}{c}1.003 \\
(0.111)\end{array}$ & $\begin{array}{c}0.955 \\
(0.125)\end{array}$ & $\begin{array}{c}1.146 \\
(0.068)\end{array}$ & $\begin{array}{c}1.083 \\
(0.071)\end{array}$ \\
\hline$H H I_{t-2}$ & $\begin{array}{c}-0.077 \\
(0.893)\end{array}$ & $\begin{array}{c}0.125 \\
(0.823)\end{array}$ & $\begin{array}{l}-0.018 \\
(0.974)\end{array}$ & $\begin{array}{c}0.280 \\
(0.612)\end{array}$ & $\begin{array}{c}0.119 \\
(0.829)\end{array}$ & $\begin{array}{c}0.363 \\
(0.505)\end{array}$ & $\begin{array}{c}0.731 \\
(0.255)\end{array}$ & $\begin{array}{c}1.341 \\
(0.037)\end{array}$ & $\begin{array}{c}0.932 \\
(0.149)\end{array}$ & $\begin{array}{c}1.145 \\
(0.074)\end{array}$ & $\begin{array}{c}0.855 \\
(0.189)\end{array}$ & $\begin{array}{c}1.227 \\
(0.052)\end{array}$ \\
\hline$C A B_{t}$ & $\begin{array}{c}0.094 \\
(0.172)\end{array}$ & $\begin{array}{c}0.093 \\
(0.170)\end{array}$ & $\begin{array}{c}0.099 \\
(0.149)\end{array}$ & $\begin{array}{c}0.097 \\
(0.145)\end{array}$ & $\begin{array}{c}0.098 \\
(0.149)\end{array}$ & $\begin{array}{c}0.093 \\
(0.158)\end{array}$ & $\begin{array}{c}0.116 \\
(0.105)\end{array}$ & $\begin{array}{c}0.093 \\
(0.170)\end{array}$ & $\begin{array}{c}0.078 \\
(0.278)\end{array}$ & $\begin{array}{c}0.092 \\
(0.182)\end{array}$ & $\begin{array}{c}0.085 \\
(0.235)\end{array}$ & $\begin{array}{c}0.093 \\
(0.174)\end{array}$ \\
\hline$C A B_{t-1}$ & $\begin{array}{l}-0.258 \\
(0.000)\end{array}$ & $\begin{array}{c}-0.247 \\
(0.000)\end{array}$ & $\begin{array}{c}-0.279 \\
(0.000)\end{array}$ & $\begin{array}{l}-0.260 \\
(0.000)\end{array}$ & $\begin{array}{l}-0.282 \\
(0.000)\end{array}$ & $\begin{array}{l}-0.259 \\
(0.000)\end{array}$ & $\begin{array}{c}-0.287 \\
(0.000)\end{array}$ & $\begin{array}{c}-0.263 \\
(0.000)\end{array}$ & $\begin{array}{l}-0.273 \\
(0.000)\end{array}$ & $\begin{array}{l}-0.257 \\
(0.000)\end{array}$ & $\begin{array}{c}-0.288 \\
(0.000)\end{array}$ & $\begin{array}{l}-0.261 \\
(0.000)\end{array}$ \\
\hline$R E E R_{t}$ & $\begin{array}{c}0.038 \\
(0.003)\end{array}$ & $\begin{array}{c}0.031 \\
(0.012)\end{array}$ & $\begin{array}{c}0.036 \\
(0.004)\end{array}$ & $\begin{array}{c}0.031 \\
(0.012)\end{array}$ & $\begin{array}{c}0.036 \\
(0.004)\end{array}$ & $\begin{array}{c}0.030 \\
(0.013)\end{array}$ & $\begin{array}{c}0.044 \\
(0.001)\end{array}$ & $\begin{array}{c}0.041 \\
(0.002)\end{array}$ & $\begin{array}{c}0.047 \\
(0.000)\end{array}$ & $\begin{array}{c}0.041 \\
(0.001)\end{array}$ & $\begin{array}{c}0.047 \\
(0.000)\end{array}$ & $\begin{array}{c}0.041 \\
(0.001)\end{array}$ \\
\hline$M 3 / G D P_{t}$ & $\begin{array}{l}-0.013 \\
(0.041)\end{array}$ & $\begin{array}{l}-0.014 \\
(0.016)\end{array}$ & $\begin{array}{l}-0.015 \\
(0.016)\end{array}$ & $\begin{array}{r}-0.016 \\
(0.007)\end{array}$ & $\begin{array}{l}-0.015 \\
(0.012)\end{array}$ & $\begin{array}{l}-0.017 \\
(0.004)\end{array}$ & $\begin{array}{l}-0.020 \\
(0.001)\end{array}$ & $\begin{array}{c}-0.023 \\
(0.000)\end{array}$ & $\begin{array}{l}-0.021 \\
(0.000)\end{array}$ & $\begin{array}{l}-0.022 \\
(0.000)\end{array}$ & $\begin{array}{c}-0.024 \\
(0.000)\end{array}$ & $\begin{array}{l}-0.022 \\
(0.000)\end{array}$ \\
\hline Unemployment $_{t}$ & $\begin{array}{c}0.381 \\
(0.000)\end{array}$ & $\begin{array}{c}0.374 \\
(0.000)\end{array}$ & $\begin{array}{c}0.394 \\
(0.000)\end{array}$ & $\begin{array}{c}0.384 \\
(0.000)\end{array}$ & $\begin{array}{c}0.387 \\
(0.000)\end{array}$ & $\begin{array}{c}0.389 \\
(0.000)\end{array}$ & $\begin{array}{c}0.375 \\
(0.000)\end{array}$ & $\begin{array}{c}0.403 \\
(0.000)\end{array}$ & $\begin{array}{c}0.405 \\
(0.000)\end{array}$ & $\begin{array}{c}0.391 \\
(0.000)\end{array}$ & $\begin{array}{c}0.415 \\
(0.000)\end{array}$ & $\begin{array}{c}0.397 \\
(0.000)\end{array}$ \\
\hline Obs. & 427 & 427 & 427 & 427 & 427 & 427 & 427 & 427 & 427 & 427 & 427 & 427 \\
\hline Log-likelihood & -128.6 & -139.5 & -133.3 & -141.2 & -136.3 & -141.7 & -123.7 & -135.0 & -125.9 & -134.2 & -124.8 & -134.6 \\
\hline
\end{tabular}

Table 7 indicates the marginal effects of connectivity measures on the probability of crisis in normal and excessive liquidity periods. For example, it is predicted that 1 percent increase in local financial connectivity, namely WCC, in BB network will reduce the probability of crisis by 4.6 percent whereas it will have almost no effect in credit boom periods.

The results of the probit models can be summarized as follows. First, an increase in financial connectivity in BB and BNB lending networks is found to be associated with a decline in probability of crisis in developed countries. Second, this effect is found to be mitigated and/or eliminated during credit boom and capital inflow periods in both networks. Finally, financial connectivity in BB lending network affects the probability of crisis both in the short-term and in the long-term, but it does not have any statistically significant impact on the probability of crisis in BNB lending network in the long-term.

\subsection{Robustness tests}

We did several robustness tests. As a first set of checks, we examine whether our findings are sensitive to the definition of crisis in Lo Duca et al. (2017). We re-estimate the models by using banking crisis dates suggested by Laeven and Valencia (2013) for 11 EU countries. Laeven and Valencia (2013) define banking crisis as "when there is significant sign of financial distress in the banking system, such as significant bank runs, losses in the banking system, and/or bank liquidations, and when significant banking policy intervention measures are taken in a country in response to significant losses in the banking system." The results are found to be robust to this definition of crisis.

Second, we use the updated banking crisis dates reported by Laeven and Valencia (2018). Compared to the crisis periods in Laeven and Valencia (2013), Laeven and Valencia (2018) suggest shorter duration for the GFC in almost all of the countries in our sample. The results are found to be robust for BNB lending network. For BB lending network, the findings are slightly different only for the lagged models. An increase in the level of financial connectivity in BB network is found to raise the 
Table 4

Results of probit models with interaction variable between credit boom periods and connectivity measures. This table presents the estimated coefficients of probit models with country fixed effects. The p-values are in parentheses. The dependent variable is a dummy variable taking a value of 1 in crisis periods, and 0 otherwise and CreditBoom is a dummy variable taking a value of 1 in credit boom periods, and 0 otherwise. Definitions of other variables are provided at the Table A.8 in the appendix A. Panels A and B report the findings for the bank-to-bank and the bank-to-non-bank lending networks, respectively. The models reported in columns with odd-numbers $(1,3,5,7,9,11)$ are contemporaneous models and those reported in columns with even-numbers $(2,4,6,8,10,12)$ are lagged models including one period lagged values of connectivity measures, CreditBoom dummy variable and the interaction variables. All of the significant lagged values of macroeconomic control variables are included in the models.

\begin{tabular}{|c|c|c|c|c|c|c|c|c|c|c|c|c|}
\hline & \multicolumn{6}{|c|}{ Panel A: Bank-to-Bank Lending } & \multicolumn{6}{|c|}{ Panel B: Bank-to-Non-Bank Lending } \\
\hline & $(1)$ & $(2)$ & (3) & $(4)$ & $(5)$ & $(6)$ & (7) & $(8)$ & $(9)$ & $(10)$ & $(11)$ & $(12)$ \\
\hline \multicolumn{13}{|l|}{ Connectivity Measure } \\
\hline $\operatorname{Ln}(F C)$ & $\begin{array}{l}-2.709 \\
(0.000)\end{array}$ & $\begin{array}{c}-1.173 \\
(0.029)\end{array}$ & & & & & $\begin{array}{l}-2.903 \\
(0.000)\end{array}$ & $\begin{array}{c}-0.125 \\
(0.846)\end{array}$ & & & & \\
\hline $\operatorname{Ln}(B C C)$ & & & $\begin{array}{r}-2.091 \\
(0.000)\end{array}$ & $\begin{array}{c}-0.771 \\
(0.097)\end{array}$ & & & & & $\begin{array}{l}-1.518 \\
(0.002)\end{array}$ & $\begin{array}{c}-0.664 \\
(0.173)\end{array}$ & & \\
\hline $\operatorname{Ln}(W C C)$ & & & & & $\begin{array}{l}-2.610 \\
(0.001)\end{array}$ & $\begin{array}{l}-0.568 \\
(0.436)\end{array}$ & & & & & $\begin{array}{l}-2.626 \\
(0.001)\end{array}$ & $\begin{array}{c}-0.677 \\
(0.399)\end{array}$ \\
\hline \multicolumn{13}{|l|}{ Interaction Variables } \\
\hline $\operatorname{Ln}(F C) *$ CreditBoom & $\begin{array}{c}1.875 \\
(0.054)\end{array}$ & $\begin{array}{c}0.838 \\
(0.380)\end{array}$ & & & & & $\begin{array}{c}1.629 \\
(0.247)\end{array}$ & $\begin{array}{c}0.780 \\
(0.547)\end{array}$ & & & & \\
\hline $\operatorname{Ln}(B C C) *$ CreditBoom & & & $\begin{array}{c}2.263 \\
(0.010)\end{array}$ & $\begin{array}{c}1.676 \\
(0.089)\end{array}$ & & & & & $\begin{array}{c}0.595 \\
(0.652)\end{array}$ & $\begin{array}{c}0.840 \\
(0.492)\end{array}$ & & \\
\hline $\operatorname{Ln}(W C C) *$ CreditBoom & & & & & $\begin{array}{c}2.963 \\
(0.031)\end{array}$ & $\begin{array}{c}1.676 \\
(0.270)\end{array}$ & & & & & $\begin{array}{l}-2.219 \\
(0.451)\end{array}$ & $\begin{array}{l}-0.551 \\
(0.817)\end{array}$ \\
\hline \multicolumn{13}{|l|}{ Control Variables } \\
\hline CreditBoom & $\begin{array}{c}1.590 \\
(0.013)\end{array}$ & $\begin{array}{c}0.804 \\
(0.188)\end{array}$ & $\begin{array}{c}1.769 \\
(0.002)\end{array}$ & $\begin{array}{c}1.225 \\
(0.032)\end{array}$ & $\begin{array}{c}1.183 \\
(0.008)\end{array}$ & $\begin{array}{c}0.726 \\
(0.093)\end{array}$ & $\begin{array}{c}1.524 \\
(0.124)\end{array}$ & $\begin{array}{c}0.776 \\
(0.389)\end{array}$ & $\begin{array}{c}0.805 \\
(0.361)\end{array}$ & $\begin{array}{c}0.747 \\
(0.346)\end{array}$ & $\begin{array}{c}-0.059 \\
(0.938)\end{array}$ & $\begin{array}{c}0.140 \\
(0.813)\end{array}$ \\
\hline $\operatorname{Ln}(\text { GDPpercapita })_{t}$ & $\begin{array}{c}5.337 \\
(0.000)\end{array}$ & $\begin{array}{c}5.464 \\
(0.000)\end{array}$ & $\begin{array}{c}5.678 \\
(0.000)\end{array}$ & $\begin{array}{c}5.746 \\
(0.000)\end{array}$ & $\begin{array}{c}5.659 \\
(0.000)\end{array}$ & $\begin{array}{c}5.907 \\
(0.000)\end{array}$ & $\begin{array}{c}5.659 \\
(0.000)\end{array}$ & $\begin{array}{c}5.725 \\
(0.000)\end{array}$ & $\begin{array}{c}5.740 \\
(0.000)\end{array}$ & $\begin{array}{c}5.619 \\
(0.000)\end{array}$ & $\begin{array}{c}5.826 \\
(0.000)\end{array}$ & $\begin{array}{c}5.606 \\
(0.000)\end{array}$ \\
\hline $\operatorname{Ln}(\text { PrivCredit } / G D P)_{t}$ & $\begin{array}{c}0.632 \\
(0.029)\end{array}$ & $\begin{array}{c}0.791 \\
(0.005)\end{array}$ & $\begin{array}{c}0.654 \\
(0.023)\end{array}$ & $\begin{array}{c}0.738 \\
(0.009)\end{array}$ & $\begin{array}{c}0.703 \\
(0.013)\end{array}$ & $\begin{array}{c}0.746 \\
(0.008)\end{array}$ & $\begin{array}{c}0.695 \\
(0.020)\end{array}$ & $\begin{array}{c}0.832 \\
(0.004)\end{array}$ & $\begin{array}{c}0.770 \\
0.010)\end{array}$ & $\begin{array}{c}0.819 \\
(0.006)\end{array}$ & $\begin{array}{c}0.806 \\
(0.007)\end{array}$ & $\begin{array}{c}0.842 \\
(0.005)\end{array}$ \\
\hline$H H I_{t}$ & $\begin{array}{c}1.182 \\
(0.047)\end{array}$ & $\begin{array}{c}1.814 \\
(0.001)\end{array}$ & $\begin{array}{c}1.676 \\
(0.003)\end{array}$ & $\begin{array}{c}1.947 \\
(0.000)\end{array}$ & $\begin{array}{c}1.790 \\
(0.001)\end{array}$ & $\begin{array}{c}1.965 \\
(0.000)\end{array}$ & $\begin{array}{c}1.300 \\
(0.063)\end{array}$ & $\begin{array}{c}2.457 \\
(0.000)\end{array}$ & $\begin{array}{c}1.823 \\
(0.005)\end{array}$ & $\begin{array}{c}2.412 \\
(0.000)\end{array}$ & $\begin{array}{c}1.927 \\
(0.002)\end{array}$ & $\begin{array}{c}2.476 \\
(0.000)\end{array}$ \\
\hline$H H I_{t-1}$ & $\begin{array}{l}-0.017 \\
(0.977)\end{array}$ & $\begin{array}{c}0.011 \\
(0.985)\end{array}$ & $\begin{array}{c}0.023 \\
(0.969)\end{array}$ & $\begin{array}{c}0.309 \\
(0.587)\end{array}$ & $\begin{array}{c}0.241 \\
(0.670)\end{array}$ & $\begin{array}{c}0.415 \\
(0.459)\end{array}$ & $\begin{array}{c}0.915 \\
(0.152)\end{array}$ & $\begin{array}{c}1.228 \\
(0.067)\end{array}$ & $\begin{array}{c}1.139 \\
(0.074)\end{array}$ & $\begin{array}{c}1.012 \\
(0.106)\end{array}$ & $\begin{array}{c}1.256 \\
(0.048)\end{array}$ & $\begin{array}{c}1.097 \\
(0.069)\end{array}$ \\
\hline$H H I_{t-2}$ & $\begin{array}{c}0.077 \\
(0.893)\end{array}$ & $\begin{array}{c}0.183 \\
(0.745)\end{array}$ & $\begin{array}{c}0.138 \\
(0.809)\end{array}$ & $\begin{array}{c}0.288 \\
(0.606)\end{array}$ & $\begin{array}{c}0.287 \\
(0.609)\end{array}$ & $\begin{array}{c}0.400 \\
(0.466)\end{array}$ & $\begin{array}{c}0.708 \\
(0.273)\end{array}$ & $\begin{array}{c}1.370 \\
(0.033)\end{array}$ & $\begin{array}{c}0.905 \\
(0.161)\end{array}$ & $\begin{array}{c}1.161 \\
(0.070)\end{array}$ & $\begin{array}{c}0.799 \\
(0.221)\end{array}$ & $\begin{array}{c}1.234 \\
(0.051)\end{array}$ \\
\hline$C A B_{t}$ & $\begin{array}{c}0.109 \\
(0.114)\end{array}$ & $\begin{array}{c}0.098 \\
(0.152)\end{array}$ & $\begin{array}{c}0.112 \\
(0.106)\end{array}$ & $\begin{array}{c}0.100 \\
(0.136)\end{array}$ & $\begin{array}{c}0.109 \\
(0.110)\end{array}$ & $\begin{array}{c}0.095 \\
(0.149)\end{array}$ & $\begin{array}{c}0.136 \\
(0.058)\end{array}$ & $\begin{array}{c}0.096 \\
(0.158)\end{array}$ & $\begin{array}{c}0.097 \\
(0.175)\end{array}$ & $\begin{array}{c}0.094 \\
(0.171)\end{array}$ & $\begin{array}{c}0.099 \\
(0.165)\end{array}$ & $\begin{array}{c}0.094 \\
(0.169)\end{array}$ \\
\hline$C A B_{t-1}$ & $\begin{array}{l}-0.242 \\
(0.000)\end{array}$ & $\begin{array}{l}-0.256 \\
(0.000)\end{array}$ & $\begin{array}{l}-0.265 \\
(0.000)\end{array}$ & $\begin{array}{l}-0.265 \\
(0.000)\end{array}$ & $\begin{array}{l}-0.269 \\
(0.000)\end{array}$ & $\begin{array}{l}-0.265 \\
(0.000)\end{array}$ & $\begin{array}{l}-0.275 \\
(0.000)\end{array}$ & $\begin{array}{l}-0.268 \\
(0.000)\end{array}$ & $\begin{array}{c}-0.261 \\
(0.000)\end{array}$ & $\begin{array}{l}-0.262 \\
(0.000)\end{array}$ & $\begin{array}{l}-0.273 \\
(0.000)\end{array}$ & $\begin{array}{l}-0.266 \\
(0.000)\end{array}$ \\
\hline$R E E R_{t}$ & $\begin{array}{c}0.038 \\
(0.003)\end{array}$ & $\begin{array}{c}0.032 \\
(0.008)\end{array}$ & $\begin{array}{c}0.036 \\
(0.004)\end{array}$ & $\begin{array}{c}0.032 \\
(0.010)\end{array}$ & $\begin{array}{c}0.036 \\
(0.004)\end{array}$ & $\begin{array}{c}0.032 \\
(0.010)\end{array}$ & $\begin{array}{c}0.043 \\
(0.001)\end{array}$ & $\begin{array}{c}0.042 \\
(0.001)\end{array}$ & $\begin{array}{c}0.045 \\
(0.001)\end{array}$ & $\begin{array}{c}0.041 \\
(0.001)\end{array}$ & $\begin{array}{c}0.044 \\
(0.001)\end{array}$ & $\begin{array}{c}0.042 \\
(0.001)\end{array}$ \\
\hline$M 3 / G D P_{t}$ & $\begin{array}{l}-0.012 \\
(0.046)\end{array}$ & $\begin{array}{c}-0.014 \\
(0.017)\end{array}$ & $\begin{array}{c}-0.014 \\
(0.014)\end{array}$ & $\begin{array}{l}-0.015 \\
(0.013)\end{array}$ & $\begin{array}{l}-0.015 \\
(0.011)\end{array}$ & $\begin{array}{l}-0.016 \\
(0.006)\end{array}$ & $\begin{array}{l}-0.020 \\
(0.001)\end{array}$ & $\begin{array}{l}-0.023 \\
(0.000)\end{array}$ & $\begin{array}{l}-0.021 \\
(0.000)\end{array}$ & $\begin{array}{l}-0.022 \\
(0.000)\end{array}$ & $\begin{array}{l}-0.023 \\
(0.000)\end{array}$ & $\begin{array}{l}-0.023 \\
(0.000)\end{array}$ \\
\hline Unemployment $_{t}$ & $\begin{array}{c}0.398 \\
(0.000)\end{array}$ & $\begin{array}{c}0.377 \\
(0.000)\end{array}$ & $\begin{array}{c}0.415 \\
(0.000)\end{array}$ & $\begin{array}{c}0.391 \\
(0.000)\end{array}$ & $\begin{array}{c}0.408 \\
(0.000)\end{array}$ & $\begin{array}{c}0.398 \\
(0.000)\end{array}$ & $\begin{array}{c}0.391 \\
(0.000)\end{array}$ & $\begin{array}{c}0.410 \\
(0.000)\end{array}$ & $\begin{array}{c}0.420 \\
(0.000)\end{array}$ & $\begin{array}{c}0.397 \\
(0.000)\end{array}$ & $\begin{array}{c}0.432 \\
(0.000)\end{array}$ & $\begin{array}{c}0.401 \\
(0.000)\end{array}$ \\
\hline Obs. & 427 & 427 & 427 & 427 & 427 & 427 & 427 & 427 & 427 & 427 & 427 & 427 \\
\hline Log-likelihood & -126.6 & -138.6 & -129.7 & -139.0 & -133.7 & -140.4 & -123.4 & -134.5 & -126.1 & -133.7 & -124.6 & -134.2 \\
\hline
\end{tabular}

probability of crisis significantly in lagged credit boom and capital inflow models, and coefficient of interaction variable is found to be statistically insignificant in credit boom models.

As a third check for crisis, we use the alternative definition suggested by European Systemic Risk Board (Lo Duca et al., 2017). The end year of the crisis is determined based on the end of the acute phase of the crisis and does not include postcrisis adjustment period. We find that the results are robust for capital inflow models in BB and BNB lending networks, and for credit boom models in BNB lending network. For BB lending network credit boom models, although the coefficient of connectivity measure is found to be negative and statistically significant in contemporaneous models, the coefficient of interaction variable is found to be insignificant. Different findings obtained in the BB lending network for the credit boom models can be explained by the decline in the duration of crisis periods. In particular, Laeven and Valencia (2013, 2018) predict shorter duration to avoid labeling a non-systemic event as a systemic banking crisis. Similarly, European Systemic Risk Board predicts shorter duration of crisis by excluding post-crisis adjustment period. Policy interventions enforced by countries following the credit boom periods, as we observed in the aftermath of the recent GFC, have a potential to absorb the destabilizing impacts of credit boom on financial stability and shorten the acute phase of the crisis. These policy interventions during the credit boom periods could explain why the coefficient of interaction variable turns out to be statistically insignificant in credit boom models with alternative definitions of crisis. On the other hand, since there is no policy intervention for capital inflows such as limitations beyond certain threshold in the upsurge periods, we expect that the impact 
Table 5

Results of probit models with interaction variable between capital inflow periods and connectivity measures. This table presents the estimated coefficients of probit models with country fixed effects. The p-values are in parentheses. The dependent variable is a dummy variable taking a value of 1 in crisis periods, and 0 otherwise and CapitalInflow is a dummy variable taking a value of 1 in capital inflow periods, and 0 otherwise. Definitions of other variables are provided at the Table A.8 in the appendix A. Panels A and B report the findings for the bank-to-bank and the bank-to-non-bank lending networks, respectively. The models reported in columns with odd-numbers $(1,3,5,7,9,11)$ are contemporaneous models and those reported in columns with even-numbers $(2,4,6,8,10,12)$ are lagged models including one period lagged values of connectivity measures, CapitalInflow dummy variable and the interaction variables. All of the significant lagged values of macroeconomic control variables are included in the models.

\begin{tabular}{|c|c|c|c|c|c|c|c|c|c|c|c|c|}
\hline & \multicolumn{6}{|c|}{ Panel A: Bank-to-Bank Lending } & \multicolumn{6}{|c|}{ Panel B: Bank-to-Non-Bank Lending } \\
\hline & (1) & $(2)$ & (3) & (4) & (5) & (6) & $(7)$ & $(8)$ & (9) & $(10)$ & $(11)$ & $(12)$ \\
\hline \multicolumn{13}{|l|}{ Connectivity Measure } \\
\hline $\operatorname{Ln}(F C)$ & $\begin{array}{l}-2.845 \\
(0.000)\end{array}$ & $\begin{array}{l}-1.224 \\
(0.014)\end{array}$ & & & & & $\begin{array}{l}-2.918 \\
(0.000)\end{array}$ & $\begin{array}{c}-0.209 \\
(0.736)\end{array}$ & & & & \\
\hline $\operatorname{Ln}(B C C)$ & & & $\begin{array}{l}-1.695 \\
(0.000)\end{array}$ & $\begin{array}{c}-0.566 \\
(0.078)\end{array}$ & & & & & $\begin{array}{l}-1.712 \\
(0.000)\end{array}$ & $\begin{array}{c}-0.672 \\
(0.155)\end{array}$ & & \\
\hline $\operatorname{Ln}(W C C)$ & & & & & $\begin{array}{l}-2.159 \\
(0.001)\end{array}$ & $\begin{array}{l}-0.527 \\
(0.430)\end{array}$ & & & & & $\begin{array}{l}-3.243 \\
(0.000)\end{array}$ & $\begin{array}{l}-0.979 \\
(0.223)\end{array}$ \\
\hline \multicolumn{13}{|l|}{ Interaction Variables } \\
\hline $\operatorname{Ln}(F C) *$ CapitalInflow & $\begin{array}{c}3.063 \\
(0.001)\end{array}$ & $\begin{array}{c}1.908 \\
(0.032)\end{array}$ & & & & & $\begin{array}{c}2.281 \\
(0.022)\end{array}$ & $\begin{array}{c}1.120 \\
(0.219)\end{array}$ & & & & \\
\hline $\operatorname{Ln}(B C C) *$ CapitalInflow & & & $\begin{array}{c}1.912 \\
(0.024)\end{array}$ & $\begin{array}{c}1.544 \\
(0.063)\end{array}$ & & & & & $\begin{array}{c}2.253 \\
(0.014)\end{array}$ & $\begin{array}{c}0.949 \\
(0.298)\end{array}$ & & \\
\hline $\operatorname{Ln}(W C C) *$ CapitalInflow & & & & & $\begin{array}{c}3.531 \\
(0.023)\end{array}$ & $\begin{array}{c}3.280 \\
(0.036)\end{array}$ & & & & & $\begin{array}{c}3.392 \\
(0.067)\end{array}$ & $\begin{array}{c}1.982 \\
(0.282)\end{array}$ \\
\hline \multicolumn{13}{|l|}{ Control Variables } \\
\hline CapitalInflow & $\begin{array}{c}1.185 \\
(0.033)\end{array}$ & $\begin{array}{c}1.064 \\
(0.034)\end{array}$ & $\begin{array}{c}0.498 \\
(0.323)\end{array}$ & $\begin{array}{c}0.840 \\
(0.069)\end{array}$ & $\begin{array}{c}0.262 \\
(0.516)\end{array}$ & $\begin{array}{c}0.700 \\
(0.065)\end{array}$ & $\begin{array}{c}0.858 \\
(0.185)\end{array}$ & $\begin{array}{c}0.671 \\
(0.217)\end{array}$ & $\begin{array}{c}0.696 \\
(0.205)\end{array}$ & $\begin{array}{c}0.522 \\
(0.293)\end{array}$ & $\begin{array}{c}0.170 \\
(0.698)\end{array}$ & $\begin{array}{c}0.411 \\
(0.299)\end{array}$ \\
\hline $\operatorname{Ln}(\text { GDPpercapita })_{t}$ & $\begin{array}{c}5.405 \\
(0.000)\end{array}$ & $\begin{array}{c}5.345 \\
(0.000)\end{array}$ & $\begin{array}{c}5.727 \\
(0.000)\end{array}$ & $\begin{array}{c}5.611 \\
(0.000)\end{array}$ & $\begin{array}{c}5.655 \\
(0.000)\end{array}$ & $\begin{array}{c}5.778 \\
(0.000)\end{array}$ & $\begin{array}{c}5.674 \\
(0.000)\end{array}$ & $\begin{array}{c}5.523 \\
(0.000)\end{array}$ & $\begin{array}{c}5.975 \\
(0.000)\end{array}$ & $\begin{array}{c}5.450 \\
(0.000)\end{array}$ & $\begin{array}{c}5.996 \\
(0.000)\end{array}$ & $\begin{array}{c}5.510 \\
(0.000)\end{array}$ \\
\hline $\operatorname{Ln}(\text { Priv } \text { Credit } / G D P)_{t}$ & $\begin{array}{c}0.701 \\
(0.015)\end{array}$ & $\begin{array}{c}0.787 \\
(0.006)\end{array}$ & $\begin{array}{c}0.685 \\
(0.015)\end{array}$ & $\begin{array}{c}0.804 \\
(0.004)\end{array}$ & $\begin{array}{c}0.757 \\
(0.007)\end{array}$ & $\begin{array}{c}0.802 \\
(0.005)\end{array}$ & $\begin{array}{c}0.726 \\
(0.013)\end{array}$ & $\begin{array}{c}0.871 \\
(0.003)\end{array}$ & $\begin{array}{c}0.797 \\
(0.006)\end{array}$ & $\begin{array}{c}0.885 \\
(0.002)\end{array}$ & $\begin{array}{c}0.823 \\
(0.005)\end{array}$ & $\begin{array}{c}0.891 \\
(0.002)\end{array}$ \\
\hline$H H I_{t}$ & $\begin{array}{c}1.133 \\
(0.064)\end{array}$ & $\begin{array}{c}1.820 \\
(0.001)\end{array}$ & $\begin{array}{c}1.728 \\
(0.002)\end{array}$ & $\begin{array}{c}1.901 \\
(0.000)\end{array}$ & $\begin{array}{c}1.831 \\
(0.001)\end{array}$ & $\begin{array}{c}1.958 \\
(0.000)\end{array}$ & $\begin{array}{c}1.319 \\
(0.061)\end{array}$ & $\begin{array}{c}2.374 \\
(0.000)\end{array}$ & $\begin{array}{c}1.822 \\
(0.006)\end{array}$ & $\begin{array}{c}2.381 \\
(0.000)\end{array}$ & $\begin{array}{c}2.050 \\
(0.001)\end{array}$ & $\begin{array}{c}2.453 \\
(0.000)\end{array}$ \\
\hline$H H I_{t-1}$ & $\begin{array}{l}-0.118 \\
(0.839)\end{array}$ & $\begin{array}{c}0.018 \\
(0.976)\end{array}$ & $\begin{array}{l}-0.001 \\
(0.999)\end{array}$ & $\begin{array}{c}0.413 \\
(0.468)\end{array}$ & $\begin{array}{c}0.143 \\
(0.796)\end{array}$ & $\begin{array}{c}0.527 \\
(0.356)\end{array}$ & $\begin{array}{c}0.844 \\
(0.182)\end{array}$ & $\begin{array}{c}1.093 \\
(0.108)\end{array}$ & $\begin{array}{c}1.135 \\
(0.076)\end{array}$ & $\begin{array}{c}0.897 \\
(0.155)\end{array}$ & $\begin{array}{c}1.211 \\
(0.056)\end{array}$ & $\begin{array}{c}1.040 \\
(0.086)\end{array}$ \\
\hline$H H I_{t-2}$ & $\begin{array}{l}-0.059 \\
(0.919)\end{array}$ & $\begin{array}{c}0.007 \\
(0.990)\end{array}$ & $\begin{array}{c}0.003 \\
(0.995)\end{array}$ & $\begin{array}{c}0.166 \\
(0.766)\end{array}$ & $\begin{array}{c}0.127 \\
(0.819)\end{array}$ & $\begin{array}{c}0.254 \\
(0.645)\end{array}$ & $\begin{array}{c}0.774 \\
(0.231)\end{array}$ & $\begin{array}{c}1.309 \\
(0.042)\end{array}$ & $\begin{array}{c}0.997 \\
(0.126)\end{array}$ & $\begin{array}{c}1.122 \\
(0.081)\end{array}$ & $\begin{array}{c}0.906 \\
(0.166)\end{array}$ & $\begin{array}{c}1.185 \\
(0.062)\end{array}$ \\
\hline$C A B_{t}$ & $\begin{array}{c}0.138 \\
(0.059)\end{array}$ & $\begin{array}{c}0.103 \\
(0.128)\end{array}$ & $\begin{array}{c}0.115 \\
(0.100)\end{array}$ & $\begin{array}{c}0.104 \\
(0.121)\end{array}$ & $\begin{array}{c}0.112 \\
(0.103)\end{array}$ & $\begin{array}{c}0.094 \\
(0.154)\end{array}$ & $\begin{array}{c}0.143 \\
(0.054)\end{array}$ & $\begin{array}{c}0.099 \\
(0.144)\end{array}$ & $\begin{array}{c}0.116 \\
(0.128)\end{array}$ & $\begin{array}{c}0.101 \\
(0.144)\end{array}$ & $\begin{array}{c}0.110 \\
(0.141)\end{array}$ & $\begin{array}{c}0.101 \\
(0.140)\end{array}$ \\
\hline$C A B_{t-1}$ & $\begin{array}{l}-0.312 \\
(0.000)\end{array}$ & $\begin{array}{l}-0.260 \\
(0.000)\end{array}$ & $\begin{array}{l}-0.301 \\
(0.000)\end{array}$ & $\begin{array}{l}-0.268 \\
(0.000)\end{array}$ & $\begin{array}{l}-0.298 \\
(0.000)\end{array}$ & $\begin{array}{l}-0.263 \\
(0.000)\end{array}$ & $\begin{array}{c}-0.323 \\
(0.000)\end{array}$ & $\begin{array}{l}-0.270 \\
(0.000)\end{array}$ & $\begin{array}{c}-0.317 \\
(0.000)\end{array}$ & $\begin{array}{c}-0.267 \\
(0.000)\end{array}$ & $\begin{array}{l}-0.314 \\
(0.000)\end{array}$ & $\begin{array}{l}-0.269 \\
(0.000)\end{array}$ \\
\hline$R E E R_{t}$ & $\begin{array}{c}0.047 \\
(0.000)\end{array}$ & $\begin{array}{c}0.034 \\
(0.007)\end{array}$ & $\begin{array}{c}0.043 \\
(0.001)\end{array}$ & $\begin{array}{c}0.033 \\
(0.008)\end{array}$ & $\begin{array}{c}0.040 \\
(0.001)\end{array}$ & $\begin{array}{c}0.031 \\
(0.013)\end{array}$ & $\begin{array}{c}0.049 \\
(0.000)\end{array}$ & $\begin{array}{c}0.042 \\
(0.002)\end{array}$ & $\begin{array}{c}0.054 \\
(0.000)\end{array}$ & $\begin{array}{c}0.042 \\
(0.001)\end{array}$ & $\begin{array}{c}0.052 \\
(0.000)\end{array}$ & $\begin{array}{c}0.042 \\
(0.001)\end{array}$ \\
\hline$M 3 / G D P_{t}$ & $\begin{array}{l}-0.014 \\
(0.022)\end{array}$ & $\begin{array}{l}-0.015 \\
(0.011)\end{array}$ & $\begin{array}{l}-0.015 \\
(0.013)\end{array}$ & $\begin{array}{l}-0.017 \\
(0.005)\end{array}$ & $\begin{array}{l}-0.016 \\
(0.009)\end{array}$ & $\begin{array}{l}-0.017 \\
(0.004)\end{array}$ & $\begin{array}{l}-0.021 \\
(0.001)\end{array}$ & $\begin{array}{l}-0.023 \\
(0.000)\end{array}$ & $\begin{array}{l}-0.022 \\
(0.000)\end{array}$ & $\begin{array}{l}-0.022 \\
(0.000)\end{array}$ & $\begin{array}{l}-0.024 \\
(0.000)\end{array}$ & $\begin{array}{l}-0.022 \\
(0.000)\end{array}$ \\
\hline Unemployment $_{t}$ & $\begin{array}{c}0.403 \\
(0.000)\end{array}$ & $\begin{array}{c}0.376 \\
(0.000)\end{array}$ & $\begin{array}{c}0.401 \\
(0.000)\end{array}$ & $\begin{array}{c}0.386 \\
(0.000)\end{array}$ & $\begin{array}{c}0.400 \\
(0.000)\end{array}$ & $\begin{array}{c}0.396 \\
(0.000)\end{array}$ & $\begin{array}{c}0.391 \\
(0.000)\end{array}$ & $\begin{array}{c}0.402 \\
(0.000)\end{array}$ & $\begin{array}{c}0.425 \\
(0.000)\end{array}$ & $\begin{array}{c}0.392 \\
(0.000)\end{array}$ & $\begin{array}{c}0.426 \\
(0.000)\end{array}$ & $\begin{array}{c}0.398 \\
(0.000)\end{array}$ \\
\hline Obs. & 427 & 427 & 427 & 427 & 427 & 427 & 427 & 427 & 427 & 427 & 427 & 427 \\
\hline Log-likelihood & -122.3 & -137.1 & -130.8 & -139.5 & -133.8 & -139.5 & -120.8 & -134.3 & -122.8 & -133.7 & -123.2 & -134.0 \\
\hline
\end{tabular}

of capital inflow periods last longer and that capital inflows to have a potential to affect the probability of crisis and the relationship between financial connectivity and probability of crisis in the short-term, as well as in the long-term, irrespective of how one defines the crisis.

In addition to the alternative definition of crisis, as another robustness check, we test whether the recent GFC dominates our results by excluding the 2008-2009 period from the analysis. The results are robust to the exclusion of the recent GFC. ${ }^{16}$

Besides, we test whether two countries, US and Luxembourg, dominate the findings by excluding them from the analysis. First, US is excluded from the sample because the recent GFC was initiated in the US, and its cross-border flows are larger than other countries in the sample. Second, Luxembourg is excluded because its GDP is extremely high compared to the rest of the sample. Luxembourg is also eliminated by Martinez (2015) for having extreme values of banking flows. The results are robust to exclusion of those countries.

\footnotetext{
${ }^{16}$ We also exclude this period from the analysis for the alternative definitions of crisis described above. We observe that capital inflow models are robust for both networks and that credit boom models are robust for BNB network. For BB network, the coefficient of interaction variable turns out to be insignificant while the coefficient of connectivity measure is significant and has expected negative sign in credit boom models.
} 
Table 6

Hypothesis Testing. This table shows the combined coefficients of connectivity measures estimated from the credit boom and capital inflow models with interaction variables. The table reports $\chi^{2}$ statistics testing the hypothesis whether the combined coefficient of connectivity measure is equal to zero $\left(H_{0}: \beta_{1}+\beta_{3}=0\right)$ with its p-value. Panel A and B show the results for credit boom and capital inflow models, respectively in bank-to-bank and bank-to-nonbank lending networks. Columns labeled as $t$ show the results for contemporaneous models and columns labeled as $(t-1)$ show the results for lagged models, including one period lagged values of connectivity measure, dummy variable and the interaction variable.

\begin{tabular}{|c|c|c|c|c|c|c|c|c|}
\hline & & & \multicolumn{2}{|c|}{ FC } & \multicolumn{2}{|c|}{ BCC } & \multicolumn{2}{|c|}{ WCC } \\
\hline & & & $t$ & $(t-1)$ & $t$ & $(t-1)$ & $t$ & $(t-1)$ \\
\hline \multirow[t]{9}{*}{ Panel A } & (Credit Boom Model) & & & & & & & \\
\hline & & Bank-to-Bank Lending & & & & & & \\
\hline & & $\beta_{1}+\beta_{3}$ & -0.834 & -0.335 & 0.172 & 0.905 & 0.353 & 1.108 \\
\hline & & $\chi^{2}$ statistics & 0.92 & 0.15 & 0.05 & 1.01 & 0.09 & 0.64 \\
\hline & & $p-$ value & 0.34 & 0.70 & 0.82 & 0.31 & 0.77 & 0.42 \\
\hline & & Bank-to-Non-Bank Lending & & & & & & \\
\hline & & $\beta_{1}+\beta_{3}$ & -1.274 & 0.655 & -0.924 & 0.176 & -4.845 & -1.228 \\
\hline & & $\chi^{2}$ statistics & 0.93 & 0.28 & 0.53 & 0.02 & 2.89 & 0.29 \\
\hline & & $p$-value & 0.34 & 0.60 & 0.47 & 0.88 & 0.09 & 0.59 \\
\hline \multirow[t]{9}{*}{ Panel B } & (Capital Inflow Model) & & & & & & & \\
\hline & & Bank-to-Bank Lending & & & & & & \\
\hline & & $\beta_{1}+\beta_{3}$ & 0.218 & 0.684 & 0.218 & 0.978 & 1.372 & 2.753 \\
\hline & & $\chi^{2}$ statistics & 0.06 & 0.55 & 0.07 & 1.38 & 0.83 & 3.12 \\
\hline & & $p-$ value & 0.80 & 0.46 & 0.79 & 0.24 & 0.36 & 0.08 \\
\hline & & Bank-to-Non-Bank Lending & & & & & & \\
\hline & & $\beta_{1}+\beta_{3}$ & -0.636 & 0.911 & 0.541 & 0.277 & 0.149 & 1.003 \\
\hline & & $\chi^{2}$ statistics & 0.35 & 0.84 & 0.34 & 0.09 & 0.01 & 0.31 \\
\hline & & $p$-value & 0.55 & 0.36 & 0.56 & 0.77 & 0.93 & 0.58 \\
\hline
\end{tabular}

Table 7

Marginal Effects. This table presents the marginal effects (i.e., change in the probability of crisis because of one percent change in connectivity level) estimated from contemporaneous credit boom and capital inflow models with interaction variables, for bank-to-bank and bank-to-non-bank lending networks. Panel A shows the change estimated during non-boom and credit boom periods; Panel B shows the change estimated during non-inflow and capital inflow periods. The marginal effects for the credit boom and capital inflow periods are calculated by adding the marginal effect of the connectivity measure and its interaction with credit boom or capital inflow dummy variable.

\begin{tabular}{|c|c|c|c|c|}
\hline & \multicolumn{2}{|c|}{$\begin{array}{c}\text { Panel A } \\
\text { Credit Boom Model }\end{array}$} & \multicolumn{2}{|c|}{$\begin{array}{c}\text { Panel B } \\
\text { Capital Inflow Model }\end{array}$} \\
\hline & Non-Boom & $\overline{\text { Credit Boom }}$ & Non-Inflow & $\overline{\text { Capital Inflow }}$ \\
\hline \multicolumn{5}{|c|}{ Bank-to-Bank Lending } \\
\hline $\operatorname{Ln}\left(F C_{t}\right)$ & -0.048 & -0.011 & -0.051 & 0.005 \\
\hline $\operatorname{Ln}\left(B C C_{t}\right)$ & -0.029 & 0.002 & -0.033 & 0.003 \\
\hline $\operatorname{Ln}\left(W C C_{t}\right)$ & -0.046 & 0.001 & -0.048 & 0.014 \\
\hline \multicolumn{5}{|c|}{ Bank-to-Non-Bank Lending } \\
\hline $\operatorname{Ln}\left(F C_{t}\right)$ & -0.034 & -0.007 & -0.048 & -0.005 \\
\hline $\operatorname{Ln}\left(B C C_{t}\right)$ & -0.021 & -0.004 & -0.023 & 0.009 \\
\hline $\operatorname{Ln}\left(W C C_{t}\right)$ & -0.032 & -0.010 & -0.051 & 0.001 \\
\hline
\end{tabular}

Finally, the findings are found to be robust to alternative econometric specifications, namely the logit estimation, the linear probability model, and the random effects models. ${ }^{17}$

\section{Conclusion}

Theoretical and empirical literature indicates that financial stability of the system is crucially dependent on the level of connectivity among financial institutions. Yet, how and in which direction financial connectivity affects financial stability is not clear. This paper contributes to this debate by investigating the relationship between probability of systemic crisis and connectivity during normal, credit boom, and capital inflow periods, for different borrower types (banks and non-banks), and by defining financial connectivity at global and at individual country levels. It is found that an increase in financial connectivity in BB and BNB lending networks is associated with a decline in the probability of systemic crises, controlling for macroeconomic variables and other country characteristics. However, this effect is found to be mitigated, and even completely eliminated in excessive liquidity periods represented by credit boom and capital inflow periods. In particular, while

\footnotetext{
17 The results of robustness tests are available and would be provided upon request.
} 
an increase in the level of connectivity in BB lending network is found to increase the probability of crisis in credit boom periods, it does not have any impact in BNB lending network. On the other hand, an increase in the level of connectivity is found to increase probability of crisis in capital inflow periods in both networks, but this effect is found to be limited to short-term in the BNB lending network.

The descriptive analysis of the characteristics of BB and BNB networks reveals the following important findings: (i) in both networks, cross-border flows and connectivity decreased considerably in the year when recent GFC hit a country; (ii) a lending shift may have occurred from banks towards non-bank sector in crisis periods; (iii) BNB lending network is more stable in terms of the number and the amount of lending relationships during the overall period and recovered from the recent GFC faster than BB lending network; and (iv) the average cross-border flows borrowed/lent across BNB lending network and flows lent across BB lending network are higher in crisis periods than non-crisis periods.

The findings of the paper have several policy implications. First, policymakers should closely monitor cross-border flows because an increase in financial connectivity is found to have benefits, as well as risks. In particular, it is found that an increase in financial connectivity is associated with a decrease in the probability of crisis, but this effect is eliminated during excessive liquidity periods. Second, it is observed that the type of the borrower (i.e. bank or non-bank) plays an important role in maintaining financial stability benefits of an increase in financial connectivity. The results suggest that cross-border lending to banks has a higher potential to disturb financial stability compared to the nonbank sector lending, especially in credit boom periods. Hence, policy-makers should target to design a financial market mechanism that can reduce risks associated with an increase in financial connectivity, while maintaining its benefits. They may reduce risks by enforcing policies that encourage transfer of cross-border flows to the real economy rather than banking sector during excessive liquidity periods.

Future work could expand our analysis by investigating how the relationship between financial connectivity and stability changes in response to different shock sizes, as Acemoglu et al. (2015) argues. Such work is important as it highlights when financial connectivity serves to improve financial stability. Moreover, this study examines only the advanced economies in which any crisis initiated in these countries affect the rest of the world. This study could be expanded further by including bank flows to emerging economies that experience crises more frequently.

\section{Acknowledgments}

We would like to thank Duc Khuong Nguyen, the participants at the 2018 IPAG Paris Financial Management Conference and the anonymous referee for helpful comments.

\section{Appendix A. Data description and descriptive statistics}

See Tables A.8 and A.9.

Table A.8

Data description. This table provides information on the data used, the sources of the data and the definitions of variables used in the analysis.

\begin{tabular}{lll}
\hline Variable & Definition & Data Source \\
\hline Dependent variable & Dummy variable taking value 1 & Lo Duca et al. (2017) and \\
& for systemic crisis, 0 otherwise & BIS and Valencia (2013) \\
FC & Financial connectivity (network density) & BIS \\
BCC & Binary clustering coefficient & BIS \\
WCC & Weighted clustering coefficient & World Bank and \\
Credit Boom & Dummy variable, taking value 1 & authors' own estimations \\
& for credit boom periods, 0 otherwise. & Reinhart and Reinhart (2008) \\
Capital Inflow & Dummy variable, taking value 1 & World Bank and \\
& for capital inflow periods, 0 otherwise. & authors' own estimations \\
GDP per capita & & World Bank \\
PrivCredit/GDP & GDP per capita (constant 2010 USD) & World Bank \\
HHI & Loans provided to the private sector by & BIS and \\
CAB & domestic money banks as a share of GDP. & authors' own estimations \\
REER & Hirschman-Herfindahl Banking & World Bank \\
M3/GDP & Sector Concentration Index & World Bank \\
Unemployment & Ratio of current account balance to GDP & World Bank \\
\hline
\end{tabular}


Table A.9

Descriptive statistics. This table shows the mean, median and standard deviation of the dependent and explanatory variables. Data definitions follow those in Table A.8.

\begin{tabular}{|c|c|c|c|c|c|c|}
\hline \multirow[b]{2}{*}{ Variable } & \multicolumn{3}{|c|}{ Bank-to-Bank Lending } & \multicolumn{3}{|c|}{ Bank-to-Non-Bank Lending } \\
\hline & Mean & Median & St. Dev. & Mean & Median & St. Dev. \\
\hline Dependent variable & 0.28 & 0.00 & 0.45 & 0.28 & 0.00 & 0.45 \\
\hline FC & 0.58 & 0.59 & 0.11 & 0.54 & 0.53 & 0.09 \\
\hline BCC & 0.60 & 0.62 & 0.12 & 0.57 & 0.60 & 0.11 \\
\hline WCC & 0.81 & 0.83 & 0.11 & 0.81 & 0.81 & 0.10 \\
\hline Credit Boom & 0.10 & 0.00 & 0.30 & 0.10 & 0.00 & 0.30 \\
\hline Capital Inflow & 0.13 & 0.00 & 0.34 & 0.13 & 0.00 & 0.34 \\
\hline GDPpercapita $^{a}$ & 43.77 & 41.04 & 16.82 & 43.77 & 41.04 & 16.82 \\
\hline PrivCredit/GDP & 88.11 & 84.80 & 41.60 & 88.11 & 84.80 & 41.60 \\
\hline HHI & 0.37 & 0.32 & 0.18 & 0.39 & 0.35 & 0.17 \\
\hline $\mathrm{CAB}$ & 1.91 & 1.76 & 4.23 & 1.91 & 1.76 & 4.23 \\
\hline REER & 102.45 & 100.07 & 11.97 & 102.45 & 100.07 & 11.97 \\
\hline M3/GDP & 94.61 & 70.32 & 62.72 & 94.61 & 70.32 & 62.72 \\
\hline Unemployment & 6.67 & 6.30 & 3.43 & 6.67 & 6.30 & 3.43 \\
\hline
\end{tabular}

a Notes: Expressed in terms of constant 2010 thousand USD.

\section{Appendix B. Network measures}

This technical appendix follows from Minoiu et al. (2015).

In a weighted and directed network $G(V, E, w), V$ denote the set of nodes (countries) in the network and $v \in V$ denote a specific node within that set. Nodes are connected by links (cross-border lending relationships among countries) such that $E \subseteq V \times V$ and $\left(v, v^{\prime}\right) \in E$ if there is a link extending from node $v$ to node $v^{\prime}$. Each link is associated with a weight (normalized credit flows across any two countries) such that $w: E \rightarrow[0,1]$. Adjacent nodes (creditors and debtors) of a node $v$ (country of interest) are given by $N_{v}=N_{v}^{\text {in }} \cup N_{v}^{\text {out }}$ where $N_{v}^{\text {in }}=\left\{v^{\prime} \mid w\left(v^{\prime}, v\right)>0\right\}$ (i.e. set of creditors) and $N_{v}^{\text {out }}=\left\{v^{\prime} \mid w\left(v, v^{\prime}\right)>0\right\}$ (i.e. set of debtors). Existence of a link $\left(v, v^{\prime}\right)$ (i.e. lending relationships across any two countries) is represented by $b_{v, v^{\prime}}=1$ if $w(v, v \prime)>0$ and 0 otherwise.

Network density (Financial Connectivity, FC): It is the number of links observed in the network divided by the total possible number of links. It measures the probability of a connection between two countries in the network and shows how close the network to a complete network, and ranges between 0 and 1.

$$
F C=\frac{|E|}{|V| \times(|V|-1)}
$$

Binary Clustering Coefficient (BCC): It is the ratio of the number of triangle pattern relationships that the node actually forms to the total possible number of the triangle pattern relationships that the node can form. It expresses the likelihood that any two adjacent nodes of a country are also adjecent among themselves.

$$
B C C(v)=\frac{\sum_{v^{\prime}, \nu^{\prime \prime} \in N_{v}} b\left(v^{\prime}, v^{\prime \prime}\right)}{\left|N_{v}\right| \times\left(\left|N_{v}\right|-1\right)}
$$

Weighted Clustering Coefficient (WCC): It is the ratio of the number of triangle pattern relationships that the node actually forms to the total possible number of the triangle pattern relationships that the node can form, weighted by the size of the flows on a triangle.

$$
W C C(v)=\frac{\sum_{v^{\prime}, v^{\prime \prime} \in N_{v}} w\left(v^{\prime}, v^{\prime \prime}\right)}{\left|N_{v}\right| \times\left(\left|N_{v}\right|-1\right)}
$$

In- and out-degree: $d_{v}^{\text {in }}$ represents the total number of a node's creditors, $d_{v}^{\text {out }}$ represents the total number of a node's debtors.

$$
\begin{aligned}
& d_{v}^{\text {in }}=\sum_{v^{\prime} \in V} b_{v^{\prime}, v} \\
& d_{v}^{\text {out }}=\sum_{v^{\prime} \in V} b_{v, v^{\prime}}
\end{aligned}
$$

In- and out-strength: $s \operatorname{tr}^{\text {in }}(v)$ refers to the total amount of cross-border flows that a country borrows (node's liabilities) and $\operatorname{str}^{\text {out }}(v)$ refers to the total amount of flows that a country lends (a node's assets). Strength measures capture the intensity of financial relationships among countries. 


$$
\begin{aligned}
& \operatorname{str}^{\text {in }}(v)=\sum_{\left(v^{\prime}, v\right) \in E} w\left(v^{\prime}, v\right) \\
& \operatorname{str}^{\text {out }}(v)=\sum_{\left(v, v^{\prime}\right) \in E} w\left(v, v^{\prime}\right)
\end{aligned}
$$

Average Nearest Node Degree (ANND): ANND denotes the average in- (out-) degree of adjacent nodes connected towards (from) a node $v$. It shows how many creditors/debtors have, on average, country $v$ 's creditors/debtors have.

$$
\begin{aligned}
& \operatorname{ANND}^{\text {in,in }}(v)=\frac{\sum_{\left(v^{\prime}, v\right) \in E} d_{v^{\prime}}^{\text {in }}}{d_{v}^{\text {in }}} \\
& \operatorname{ANND}^{\text {out,in }}(v)=\frac{\sum_{\left(v^{\prime}, v\right) \in E} d_{v^{\prime}}^{\text {out }}}{d_{v}^{\text {in }}} \\
& \operatorname{ANND}^{\text {in,out }}(v)=\frac{\sum_{\left(v, v^{\prime}\right) \in E} d_{v^{\prime}}^{\text {in }}}{d_{v}^{\text {out }}} \\
& \operatorname{ANND}^{\text {out,out }}(v)=\frac{\sum_{\left(v, v^{\prime}\right) \in E} d_{v^{\prime}}^{\text {out }}}{d_{v}^{\text {out }}}
\end{aligned}
$$

Average Nearest Node Strength (ANNS): ANNS denotes the average in- (out-) strength of adjacent nodes connected to (from) a node $v$. It shows, on average, the overall amount of cross-border flows that country $v$ 's creditors/debtors have.

$$
\begin{aligned}
& \operatorname{ANNS}^{\text {in,in }}(v)=\frac{\sum_{\left(v^{\prime}, v\right) \in E^{\text {in }}} \operatorname{str}^{\text {in }}\left(v^{\prime}\right)}{d_{v}^{\text {in }}} \\
& \operatorname{ANNS}^{\text {out }, \text { in }}(v)=\frac{\sum_{\left(v^{\prime}, v\right) \in E^{\prime}} \operatorname{str}^{\text {out }}\left(v^{\prime}\right)}{d_{v}^{\text {in }}} \\
& \operatorname{ANNS}^{\text {in }, \text { out }}(v)=\frac{\sum_{\left(v, v^{\prime}\right) \in E^{\text {out }}} \operatorname{str}^{\text {in }}\left(v^{\prime}\right)}{d_{v}^{\text {out }}} \\
& \operatorname{ANNS}^{\text {out }, \text { out }}(v)=\frac{\sum_{\left(v, v^{\prime}\right) \in E^{\text {out }}} \operatorname{str}^{\text {out }}\left(v^{\prime}\right)}{d_{v}^{\text {out }}}
\end{aligned}
$$

Herfindahl-Hirschman Concentration Index (HHI): For each borrower country, it is measured as summation of the squared value of the lenders' share in borrower country's total inflows. It measures the concentration (or diversification) of a country's borrowing activities and ranges between 0 and 1. A higher value of the HHI which implies a higher concentration of borrowing is an indication of potentially higher risk associated with a particular country $v$.

$$
H H I(v)=\sum_{v^{\prime} \in N_{v}^{\text {in }}}\left(\frac{\sum_{\left(v^{\prime}, v\right) \in E} w\left(v^{\prime}, v\right)}{\sum_{\left(v^{\prime \prime}, v\right) \in E} w\left(v^{\prime \prime}, v\right)}\right)^{2}
$$

\section{References}

Acemoglu, D., Ozdaglar, A., Tahbaz-Salehi, A., 2015. Systemic risk and stability in financial networks. Am. Econ. Rev. 105 (2), $564-608$.

Aiyar, S., Calomiris, C.W., Hooley, J., Korniyenko, Y., Wieladek, T., 2014. The international transmission of bank capital requirements: evidence from the UK. J. Financ. Econ. 113 (3), 368-382.

Allen, F., Babus, A., 2009. In: Kleindorfer, P., Wind, J. (Eds.), Network-based Strategies and Competencies. Wharton School Publishing, Upper Saddle River, NJ, pp. 367-382 (Ch. Networks in finance).

Allen, F., Babus, A., Carletti, E., 2009. Financial crises: theory and evidence. Ann. Rev. Financ. Econ. 1, $97-116$.

Allen, F., Babus, A., Carletti, E., 2012. Asset commonality, debt maturity and systemic risk. J. Financ. Econ. 104 (3), $519-534$.

Allen, F., Gale, D., 2000. Financial contagion. J. Polit. Econ. 108 (1), 1-33.

Avdjiev, S., Binder, S., Sousa, R., 2018. External debt composition and domestic credit cycles. Working Papers 28. European Stability Mechanism.

Battiston, S., Delli Gatti, D., Gallegati, M., Greenwald, B., Stiglitz, J.E., 2012a. Liaisons dangereuses: increasing connectivity, risk sharing, and systemic risk. J. Econ. Dyn. Control 36 (8), 1121-1141.

Battiston, S., Gatti, D.D., Gallegati, M., Greenwald, B., Stiglitz, J.E., 2012b. Default cascades: when does risk diversification increase stability? J. Financ. Stabil. 8 (3), 138-149.

Brusco, S., Castiglionesi, F., 2007. Liquidity coinsurance, moral hazard, and financial contagion. J. Financ. 62 (5), $2275-2302$.

Caballero, J., 2015. Banking crises and financial integration: Insights from networks science. J. Int. Financ. Markets Inst. Money $34,127-146$.

Caballero, J.A., 2014. Do surges in international capital inflows influence the likelihood of banking crises? Econ. J. 126 (591), $281-316$. 
Caccioli, F., Shrestha, M., Moore, C., Farmer, J.D., 2014. Stability analysis of financial contagion due to overlapping portfolios. J. Banking Financ. 46 (1), 233245.

Chinazzi, M., Fagiolo, G., Reyes, J.A., Schiavo, S., 2013. Post-mortem examination of the international financial network. J. Econ. Dyn. Control 37 (8), 16921713.

Demirguc-Kunt, A., Detragiache, E., 1998. The Determinants of Banking Crises in Developing and Developed Countries.

Demirgüç-Kunt, A., Detragiache, E., 2005. Cross-country empirical studies of systemic bank distress: a survey. Natl. Inst. Econ. Rev. 192 (1), 68-83.

Elliott, M., Golub, B., Jackson, M.O., 2014. Financial networks and contagion. Am. Econ. Rev. 104 (10), $3115-3153$.

Fielding, D., Rewilak, J., 2015. Credit booms, financial fragility and banking crises. Econ. Lett. 136, $233-236$.

Gai, P., Kapadia, S., 2010. Contagion in financial networks. Proc. Roy. Soc. A (466), 2401-2423.

Hale, G., 2012. Bank relationships, business cycles, and financial crises. J. Int. Econ. 88 (2), 312-325.

Hattori, M., Suda, Y., 2007. Developments in a cross-border bank exposure network. Bank of Japan Working Paper 29, 20.

Jord, Schularick, M., Taylor, A.M., 2011. Financial crises, credit booms, and external imbalances: 140 years of lessons. IMF Econ. Rev. 59 (2), $340-378$.

Kalemli-Ozcan, S., Papaioannou, E., Peydro, J.L., 2013. Financial regulation, financial globalization, and the synchronization of economic activity. J. Financ. 68 (3), 1179-1228.

Kauko, K., 2012. External deficits and non-performing loans in the recent financial crisis. Econ. Lett. 115 (2), $196-199$.

Laeven, L., Valencia, F., 2013. Systemic banking crises database. IMF Econ. Rev. 61 (2), 225-270.

Laeven, L., Valencia, F., 2018. Systemic Banking Crises Revisited. IMF Working Papers 18/206. International Monetary Fund.

Lo Duca, M., Koban, A., Basten, M., Bengtsson, E., Klaus, B., Kusmierczyk, P., Lang, J.H., Detken, C., Peltonen, T.A., 2017. A new database for financial crises in European countries. Occasional Paper Series 194. European Central Bank.

Martinez, R., 2015. International Banking Flows and Credit Booms: Do Booms Go with the Flow? George Washington University. manuscript.

McGuire, P., Wooldridge, P., 2005. The bis consolidated banking statistics: structure, uses and recent enhancements. BIS Quart. Rev.

Minoiu, C., Kang, C., Subrahmanian, V., Berea, A., 2015. Does financial connectedness predict crises? Quant. Financ. 15 (4), $607-624$.

Minoiu, C., Reyes, J.A., 2013. A network analysis of global banking: 1978-2010. J. Financ. Stabil. 9 (2), $168-184$.

Nier, E., Yang, J., Yorulmazer, T., Alentorn, A., 2007. Network models and financial stability. J. Econ. Dyn. Control 31 (6), $2033-2060$.

Reinhart, C.M., Reinhart, V.R., 2008. Capital flow bonanzas: An encompassing view of the past and present. Working Paper 14321. National Bureau of Economic Research.

Schularick, M., Taylor, A.M., 2012. Credit booms gone bust: monetary policy, leverage cycles, and financial crises, 1870-2008. Am. Econ. Rev. 102 (2), 10291061.

Tabak, B.M., Takami, M., Rocha, J.M., Cajueiro, D.O., Souza, S.R., 2014. Directed clustering coefficient as a measure of systemic risk in complex banking networks. Phys. A Stat. Mech. Appl. 394, 211-216.

Tonzer, L., 2015. Cross-border interbank networks, banking risk and contagion. J. Financ. Stabil. 18, 19-32. 